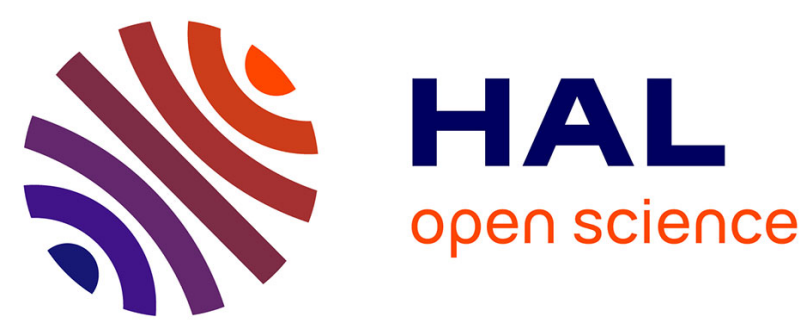

\title{
EGR1 expression: a calcium and ERK1/2 mediated PPAR-independent event involved in the antiproliferative effect of 15-deoxy-(12,14-prostaglandin J2 and Thiazolidinediones in breast cancer cells
}

Sarra Chbicheb, Xiao Yao, Jean-Luc Rodeau, Stéphane Salamone, Michel Boisbrun, Gerald Thiel, Daniel Spohn, Isabelle Grillier-Vuissoz, Yves Chapleur, Stéphane Flament, et al.

\section{- To cite this version:}

Sarra Chbicheb, Xiao Yao, Jean-Luc Rodeau, Stéphane Salamone, Michel Boisbrun, et al.. EGR1 expression: a calcium and ERK1/2 mediated PPAR-independent event involved in the antiproliferative effect of 15-deoxy-(12,14-prostaglandin J2 and Thiazolidinediones in breast cancer cells. Biochemical Pharmacology, 2011, 81 (9), pp.1087. 10.1016/j.bcp.2011.02.006 . hal-00685074

\author{
HAL Id: hal-00685074 \\ https://hal.science/hal-00685074
}

Submitted on 4 Apr 2012

HAL is a multi-disciplinary open access archive for the deposit and dissemination of scientific research documents, whether they are published or not. The documents may come from teaching and research institutions in France or abroad, or from public or private research centers.
L'archive ouverte pluridisciplinaire HAL, est destinée au dépôt et à la diffusion de documents scientifiques de niveau recherche, publiés ou non, émanant des établissements d'enseignement et de recherche français ou étrangers, des laboratoires publics ou privés. 


\section{Accepted Manuscript}

Title: EGR1 expression: a calcium and ERK1/2 mediated $\operatorname{PPAR}_{\gamma}$-independent event involved in the antiproliferative effect of 15-deoxy-(12,14-prostaglandin J2 and Thiazolidinediones in breast cancer cells

Authors: Sarra Chbicheb, Xiao Yao, Jean-Luc Rodeau,

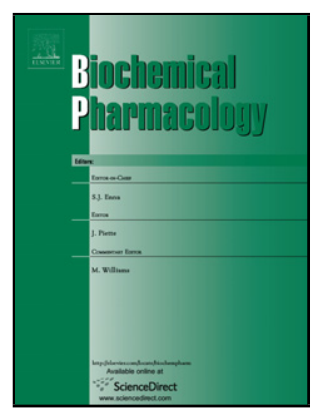

Stéphane Salamone, Michel Boisbrun, Gerald Thiel, Daniel Spohn, Isabelle Grillier-Vuissoz, Yves Chapleur, Stéphane Flament, Sabine Mazerbourg

PII: S0006-2952(11)00110-9

DOI: doi:10.1016/j.bcp.2011.02.006

Reference: BCP 10827

To appear in: $\quad B C P$

Received date: $\quad 26-11-2010$

Revised date: $\quad 10-2-2011$

Accepted date: $\quad 11-2-2011$

Please cite this article as: Chbicheb S, Yao X, Rodeau J-L, Salamone S, Boisbrun M, Thiel G, Spohn D, Grillier-Vuissoz I, Chapleur Y, Flament S, Mazerbourg S, EGR1 expression: a calcium and ERK1/2 mediated $\mathrm{PPAR}_{\gamma}$-independent event involved in the antiproliferative effect of 15-deoxy-(12,14-prostaglandin J2 and Thiazolidinediones in breast cancer cells, Biochemical Pharmacology (2010), doi:10.1016/j.bcp.2011.02.006

This is a PDF file of an unedited manuscript that has been accepted for publication. As a service to our customers we are providing this early version of the manuscript. The manuscript will undergo copyediting, typesetting, and review of the resulting proof before it is published in its final form. Please note that during the production process errors may be discovered which could affect the content, and all legal disclaimers that apply to the journal pertain. 
EGR1 EXPRESSION : A CALCIUM AND ERK1/2 MEDIATED PPAR $\gamma$ -

INDEPENDENT EVENT INVOLVED IN THE ANTIPROLIFERATIVE EFFECT OF

15-DEOXY-A12,14-PROSTAGLANDIN J2 AND THIAZOLIDINEDIONES IN

BREAST CANCER CELLS

Sarra Chbicheb ${ }^{a}$, Xiao Yao ${ }^{a}$, Jean-Luc Rodeau ${ }^{b}$, Stéphane Salamone ${ }^{c 1}$, Michel Boisbrun ${ }^{\mathrm{c}}$,

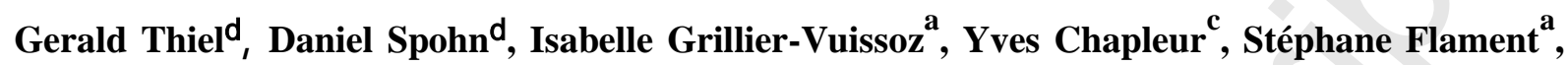

and Sabine Mazerbourg ${ }^{\mathrm{a}}$

${ }^{\mathrm{a}}$ EA 4421 Signalisation, Génomique et Recherche Translationnelle en Oncologie (SIGRETO) NancyUniversité, 54506 Vandœuvre-lès-Nancy, France

SC: sarra.chbicheb@scbiol.uhp-nancy.fr; SF: stephane.Flament@ scbiol.uhp-nancy.fr; IGV: isabelle.grillier-vuissoz@scbiol.uhp-nancy.fr; SM:sabine.mazerbourg@ scbiol.uhp-nancy.fr; XY: dawnyao@yahoo.com

${ }^{\mathrm{b}}$ Institut des Neurosciences Cellulaires et Intégratives (INCI) CNRS UPR-3212 67084 Strasbourg, France

JLR : jlr@inci-cnrs.unistra.fr

${ }^{\mathrm{c}}$ Groupe S.U.C.R.E.S., UMR 7565 CNRS, Nancy-Université, 54506 Vandœuvre-lès-Nancy, France MB : Michel.Boisbrun@pharma.uhp-nancy.fr; YC: yves.chapleur@sucres.uhp-nancy.fr; SS: stephane.salamone@pasteur.fr

${ }^{d}$ Department of Medical Biochemistry and Molecular Biology, University of Saarland Medical Center, D-66421 Homburg, Germany (G.T., D.S.)

GT: gerald.thiel@uniklinik-saarland.de; DS: daniel.spohn@uniklinik-saarland.de

Corresponding author: Sabine Mazerbourg, EA 4421 Signalisation, Génomique et Recherche Translationnelle en Oncologie (SIGRETO), Université Henri Poincaré, Nancy-Université, Faculté des Sciences, BP 70239, 54506 Vandœuvre-lès-Nancy; Cedex France. Tél : 011 33(0) 38368 42 57, Fax : 011 33(0) 3836840 01; E-mail: sabine.mazerbourg@ scbiol.uhp-nancy.fr 


\section{Abstract}

Our aim was to get new information about the Peroxisome Proliferator Activated Receptor gamma (PPAR $\gamma$ )-independent pathway involved in the antiproliferative action of PPAR $\gamma$ ligands in breast cancer cells. We investigated the effects of Troglitazone (TGZ), Ciglitazone (CGZ), Rosiglitazone (RGZ) and, 15-deoxy- $\Delta 12$,14-prostaglandin J2 (15d-PGJ $\left.\mathbf{J}_{2}\right)$ on the hormone-dependent breast cancer cell line MCF7. The early transcription factor EGRI (Early Growth Response gene 1) mRNA and protein levels peaked after 3 hours of incubation with $25 \mu \mathrm{M}$ TGZ, CGZ or $15 \mathrm{~d}_{-} \mathrm{PGJ}_{2}$ and then gradually decreased. RGZ, the most potent activator of PPAR $\gamma$, did not show this effect. The PPAR $\gamma$ antagonist GW 9662 did not block EGRl mRNA induction which also still occurred in case of PPAR $\gamma$ silencing as well as in case of treatment with the PPAR $\gamma$-inactive compound $\triangle 2$-TGZ. EGR1 mRNA induction required ERK1/2 phosphorylation which was not blocked by EGF Receptor (EGFR) inhibition. The ERK1/2 pathway was also involved in $\triangle 2$-TGZ-induced EGR1 mRNA expression in the hormone-independent breast cancer cell line MDA-MB-231. Using the fluorescent dye Fura2, we showed in MCF7 that TGZ or $\triangle 2$-TGZ induced an immediate increase in cytosolic calcium which was required for ERK1/2 phosphorylation and EGRI mRNA induction as demonstrated by calcium chelation experiments. Furthermore, in MCF7 transfected with siRNA targeting EGR1, $\triangle 2$-TGZ inhibited less efficiently cell proliferation.

Graphical abstract : Troglitazone (TGZ) and $\Delta 2-\mathrm{TGZ}$ induce an increase in cytosolic calcium leading to ERK1/2 phosphorylation and EGR1 expression in breast cancer cells, leading to growth inhibition. This event is independent of PPAR $\gamma$ and EGFR activation.

Keywords : Thiazolidinedione, Troglitazone, EGR1, calcium signaling, breast cancer 


\section{Abbreviations list:}

PPAR : peroxisome proliferator-activated receptor

EGR1 : Early Growth Response gene 1

15d-PGJ $2:$ 15-deoxy- $\Delta 12,14$-prostaglandin J2

TGZ : Troglitazone

CGZ : Ciglitazone

RGZ : Rosiglitazone

EGFR : EGF Receptor

NAB : NGFI-A-binding protein

FCS : fetal calf serum

DMSO : dimethylsulfoxide

DMEM : Dulbecco's modified Eagle's medium

dNTP : desoxynucleotide triphosphate

DTT : dithiothreitol

Ig : Immunoglobulin

MAPK : mitogen activated protein kinase

RPLPO : acidic ribosomal phosphoprotein PO 


\section{Introduction}

The peroxisome proliferator-activated receptors (PPARs) are a family of ligandactivated transcription factors belonging to the nuclear receptor superfamily [1]. Three PPAR subtypes encoded by separate genes have been identified: $\alpha, \beta / \delta$ and $\gamma$. Ligands of PPAR $\gamma$ include 15-deoxy- $\Delta 12,14$-prostaglandin $\mathrm{J} 2 \quad\left(15 \mathrm{~d}-\mathrm{PGJ}_{2}\right)$, oxidative metabolites of polyunsaturated fatty acids and synthetic compounds like thiazolidinediones (troglitazone TGZ, ciglitazone CGZ, rosiglitazone RGZ...), a class of drugs used in the treatment of type II diabetes [2]. Various PPAR $\gamma$ agonists have anti-cancer activities [3, 4]. For instance, TGZ and $15 \mathrm{~d}-\mathrm{PGJ}_{2}$ inhibit tumor growth of human prostate, colorectal or breast cancer cells in immunodeficient mice [4]. Anticancer effects of such compounds have also been observed in vitro. For example, in breast cancer cell lines, they inhibit proliferation, induce differentiation or trigger apoptosis $[5,6]$. Recently, a nonapoptotic and nonautophagic cytoplasmic vacuolation death was observed in response to $15 \mathrm{~d}-\mathrm{PGJ}_{2}$ whereas autophagy was described in response to thiazolidinediones in the same breast cancer cell line MDA-MB-231 [7, 8].

Several data suggest that the anticancer effects of PPAR $\gamma$ ligands could be the result of PPAR $\gamma$-independent events [9]. This was deduced from studies using PPAR $\gamma$ antagonists, transfection of dominant negative PPAR $\gamma$ isoforms, PPAR $\gamma$-targeted RNA interference as well as thiazolidinedione derivatives like $\Delta 2$-TGZ that could not activate PPAR $\gamma$. The proteasomal degradation of estrogen receptor alpha and cyclin D1 is an example of such a PPAR $\gamma$ independent effect triggered by several PPAR $\gamma$ ligands which has been well described in breast cancer cells [10-12]. However, in these cells, few data are available on the identity of mediators involved in the PPAR $\gamma$-independent pathway activated by thiazolidinediones. Interestingly, in human colon cancer cells, Early growth response gene 1 (EGR1) was 
identified as an early transcription factor induced after a three hour treatment with TGZ in a PPAR $\gamma$-independent manner [13].

EGR is a family of zinc-finger transcription factors (EGR1-4) with an aminoterminal activation domain, a central domain that interacts with the co-repressors NGFI-A-binding proteins 1 and 2 (NAB1 and NAB2) (except for EGR4), and a DNA binding domain consisting of three Cys2-His2 zinc fingers near the carboxy-terminal end of the protein sequence. They are described as early response genes because they are rapidly and transiently induced [14]. EGR proteins bind the consensus nucleotide sequence GCGGGGGCG to regulate expression of target genes [15]. EGR1, (also known as NGF-1A, KROX24, ZIF268, and TIS8) is a nuclear phosphoprotein that has been reported to be rapidly induced by serum, growth factors, ultraviolet light, ionizing radiations, mechanical injury, and stress. Thus, EGR1 is involved in a variety of cell processes including growth, differentiation, angiogenesis, wound healing and apoptosis. In prostate cancer cells and few other models, EGR1 is described as a protumoral factor contributing to regulation of genes which are critical for cell cycle progression and counteracting apoptosis [16]. In contrast, EGR1 expression is absent or very weak not only in several human breast cancer cell lines compared to immortalized normal human mammary cell lines (MCF10A and 184A1N4), but also in breast cancer tissues compared to normal breast tissue [17, 18]. Moreover, induced-overexpression of EGR1 negatively regulates the growth of the breast cancer cell line ZR75 [19]. These findings suggest that in breast cancer cells and tissues, reduced expression of EGR1 could enhance tumorigenesis while EGR1 overexpression could be linked to growth inhibition.

In an effort to better understand the intracellular mode of action of thiazolidinediones, the aim of our study was 1) to determine if the potential growth inhibitor EGR1 could be an 
element of their signaling in breast cancer cells, 2) to evaluate the role of the nuclear receptors PPAR $\gamma$ in this process and 3) to characterize the cellular and molecular events leading to this response. Our studies performed in the hormone-dependent cell line MCF7 show that TGZ, CGZ and $15 d-P G J_{2}$ induce the early expression of EGR1 in a PPAR $\gamma$-independent manner. In contrast, RGZ, the most potent PPAR $\gamma$ agonist, did not stimulate EGR1 expression. EGR1 induction was associated with ERK activation but the transactivation of EGFR was not involved. Similar results were observed in the hormone-independent breast cancer cell line MDA-MB-231. Furthermore, an early increase in cytosolic calcium appeared to be a key actor in the signaling pathway leading to EGRl expression. Finally, siRNA experiments demonstrated that EGR1 was as a mediator of the inhibition of proliferation triggered by $\Delta 2$ TGZ in MCF7 cells. 


\section{Materials and Methods}

\subsection{Cell culture and reagents}

MCF7 and MDA-MB-231 human breast cancer cell lines were obtained from American Type Culture Collection (Rockville, MD, USA). Both cell lines were grown at $37^{\circ} \mathrm{C}$ under 5\% $\mathrm{CO}_{2}$ in phenol red Dulbecco's modified Eagle medium (DMEM, Invitrogen, Cergy Pontoise, France) for MCF-7 and in L-15 medium (Invitrogen) for MDA-MB-231. These media were supplemented with $10 \%$ fetal calf serum (FCS) (Sigma-Aldrich, Lyon, France) and $2 \mathrm{mM} \mathrm{L-glutamine} \mathrm{(Invitrogen).}$

TGZ, AG1478, A23187 ionophore (Sigma-Aldrich), CGZ, RGZ, GW9662, U0126, PD153035, SP600125, SB203580, BAPTA-AM (Calbiochem Merck, Darmstadt, Germany), 15d-PGJ $\mathrm{d}_{2}$ (Interchim, Montluçon, France) were dissolved in dimethylsulfoxide (DMSO; Sigma-Aldrich). Recombinant human Epidermal Growth Factor (EGF) (Invitrogen) was resuspended in PBS. The synthesis of $\Delta 2$-TGZ was achieved according to slight modifications of known procedures $[17,20]$. Experimental details will be published elsewhere. The identity and purity of this synthetic derivative were verified by proton nuclear magnetic resonance and elemental analysis. This compound was also dissolved in DMSO.

\subsection{Cell treatment}

After seeding and 24 hours of incubation to allow for cell attachment, cells were washed with PBS and the medium was replaced with phenol red-free DMEM (MCF7) or L-15 medium (MDA-MB-231) supplemented with 1\% FCS and 2 mM L-glutamine. After 24 hours, cells were washed with PBS and treated with either DMSO, $15 \mathrm{~d}^{-\mathrm{PGJ}} \mathrm{J}_{2}$, thiazolidinediones, EGF, or the calcium ionophore A23187 at the indicated concentrations and times in phenol red-free, FCS-free DMEM for MCF7 or 1\% FCS L-15 medium for MDA-MB-231 supplemented with $2 \mathrm{mM} \mathrm{L-glutamine.} \mathrm{To} \mathrm{test} \mathrm{the} \mathrm{involvement} \mathrm{of} \mathrm{the} \mathrm{MAPK} \mathrm{and} \mathrm{calcium}$ pathways or the PPAR $\gamma$ and EGF receptors, cells were treated with different inhibitors for 30 
minutes prior to PPAR $\gamma$ ligands exposure. Cells were then collected for RNA or protein extraction.

\subsection{Semi-quantitative RT-PCR}

Cells were seeded in 6-well plates at a density of $5 \times 10^{5}$ cells/well (MCF7 cells) or 4 x $10^{5}$ cells/well (MDA-MB-231 cells) in $2 \mathrm{~mL}$ of medium with $10 \% \mathrm{FCS}$ and $2 \mathrm{mM} \mathrm{L-}$ glutamine. Cells were treated as previously described. Total RNA was extracted using TRIZOL reagent (Invitrogen) according to the manufacturer's instructions. cDNA was synthesized in $25 \mu \mathrm{L}$ volume containing $1 \mu \mathrm{g}$ RNA, 12 ng random hexamer primer, $1 \mathrm{X}$ Invitrogen Buffer, $4 \mathrm{mM}$ DTT, $0.1 \mathrm{mM}$ of each dNTP, $4 \mathrm{U}$ RNase inhibitor and $75 \mathrm{U}$ of MMLV reverse transcriptase (Invitrogen). The mixture was incubated for 10 minutes at $25^{\circ} \mathrm{C}$, for 110 minutes at $37^{\circ} \mathrm{C}$ and subsequently for 10 minutes at $70^{\circ} \mathrm{C}$ in order to stop the reaction. The cDNA were further amplified by PCR. The specific primer sequences are as follows: EGR1 (NM_001964) forward 5'-GGCCACCTCCTCTCTCTCTT-3', reverse 5'TGTTGGCCAATAGACCTTCC-3'; PPAR $\quad$ (NM_138712) forward 5'GACCACTCCCACTCCTTT-3'， reverse 5'-CGACATTCAATTGCCATGAG-3'; EGFR (NM_005228) forward 5'-AAGCTCACGCAGTTGGGCAC-3', reverse 5'GGTTCTGGAAGTCCATCGAC-3'; NAB2 (NM_005967) forward 5'GACCCTGCAGCCCAGACTC-3'， reverse 5'-CTTCGATAGTGGTGACGGACC-3'; RPLPO (NM_053275) forward 5'-ACAACCCAGCTCTGGAGAAA-3', reverse 5'TCGTTTGTACCCGTTGATGA-3'. PCR was carried out in a thermal cycler (Eppendorf, Le Pecq, France) in a final volume of $25 \mu \mathrm{L}$ containing $2 \mu \mathrm{L}$ cDNA, $1 \mathrm{X}$ EconoTaq ${ }^{\mathrm{TM}}$ Reaction Buffer $(-\mathrm{Mg}), 1.5 \mathrm{mM} \mathrm{MgCl} 2,0.2 \mathrm{mM}$ of dNTP mix, $0.2 \mu \mathrm{M}$ of each primer and $2.5 \mathrm{U}$ EconoTaq. Negative controls were always included. Amplification was carried out under the following conditions: (1) initial denaturation $94^{\circ} \mathrm{C}$ for 2 minutes; (2) $94^{\circ} \mathrm{C}$ for $30 \mathrm{~s}, 58^{\circ} \mathrm{C}$ for 
$30 \mathrm{~s}$ and $72^{\circ} \mathrm{C}$ for $45 \mathrm{~s} .30 \mathrm{PCR}$ cycles were performed for gene amplification, with the exception of RPLPO amplified with 25 cycles. (3) 10 minutes extension step at $72^{\circ} \mathrm{C}$. The number of cycles was chosen to realize the analysis in the linear phase of the PCR reaction. $20 \mu \mathrm{L}$ of the PCR products were mixed with loading buffer $(5 \mu \mathrm{l})$ and submitted to electrophoresis in a $1.2 \%$ agarose gel at $90 \mathrm{~V}$ for 35 minutes at room temperature. The gel was stained with ethidium bromide, viewed and photographed on a UV-transilluminator (GelDoc 2000, Bio-Rad Laboratories, Marnes-La-Coquette, France). A software package (Quantity One v.4.3.1, Bio-Rad Laboratories) was used to quantify the PCR products.

\subsection{RNA interference}

The small-interfering RNA (siRNA) duplexes for targeting PPAR $\gamma$, EGR1 and EGFR as well as a scrambled sequence (control siRNA duplex, negative control) were purchased from Eurogentec (Angers, France). The sequences are shown in Table 1. MCF7 cells (1.45 x $10^{5}$ ) were plated overnight in twelve-well culture plates in DMEM supplemented with $10 \%$ FCS and $2 \mathrm{mM} \mathrm{L-glutamine.} \mathrm{Cells} \mathrm{were} \mathrm{transiently} \mathrm{transfected} \mathrm{with} \mathrm{either} \mathrm{target} \mathrm{gene} \mathrm{siRNA}$ (200 $\mathrm{nM}$ of the mix duplex 1 and duplex 2 or $200 \mathrm{nM}$ of one duplex) or negative control siRNA-sequence (Table 1) using the Oligofectamine ${ }^{\mathrm{TM}}$ Reagent (Invitrogen) as described by the manufacturer. The concentration of siRNA used was standardized to get maximum knockdown without affecting the viability of the cells. After 24 hours, cells were washed with PBS and the medium was replaced with phenol red-free DMEM supplemented with 1\% FCS and $2 \mathrm{mM} \mathrm{L-glutamine.} 24$ hours later, cells were treated in phenol red-free and FCS-free DMEM with $2 \mathrm{mM}$ L-glutamine and harvested for further analyses. 


\subsection{Nuclear protein extracts}

At the end of the treatment, cells were washed twice with cold PBS and collected in 1 mL PBS. Nuclear and cytoplasmic extracts were prepared by detergent lysis. Briefly, after pelleting, the cells were incubated in hypotonic solution (10 mM Hepes-KOH, pH 7.9, 1.5 $\mathrm{mM} \mathrm{MgCl} 2,10 \mathrm{mM} \mathrm{KCl}, 0.5 \mathrm{mM}$ dithiothreitol (DTT), $0.5 \%$ Nonidet P40, 2.5X Protease inhibitor cocktail tablet, Roche) for 15 minutes on ice and vortexed each 5 minutes. Nuclei were collected by centrifugation at $13000 \mathrm{rpm}$ for 5 minutes at $4^{\circ} \mathrm{C}$. The nuclei pellet was then resuspended in a hypertonic buffer (10 mM Hepes-KOH pH 7.9, 25\% Glycerol, $420 \mathrm{nM}$ $\mathrm{NaCl}, 1.5 \mathrm{mM} \mathrm{MgCl}_{2}, 0.2 \mathrm{~mm}$ EDTA, $0.5 \mathrm{mM}$ DTT, 0.5\% Triton, 2.5X Protease inhibitor cocktail tablet, Roche, Fontenay sous Bois, France). Nuclei were incubated for 15 minutes at $4^{\circ} \mathrm{C}$ with shaking. After centrifugation $\left(13000 \mathrm{rpm}, 5\right.$ minutes, $\left.4^{\circ} \mathrm{C}\right)$, the supernatant containing nuclear proteins was stored at $-80^{\circ} \mathrm{C}$. Protein concentrations were determined by the Bradford method (Bio-Rad Protein Assay, Bio-Rad Laboratories).

\subsection{Western immunobloting}

For EGR1 detection, $30 \mu \mathrm{g}$ of nuclear proteins were mixed with $2 \mathrm{X}$ Laemmli buffer, boiled $\left(100^{\circ} \mathrm{C}, 5\right.$ minutes) and separated by $10 \%$ SDS-PAGE. For other protein analyses, cells were harvested by addition of $150 \mu \mathrm{L} 2 \mathrm{X}$ Laemmli buffer and boiled. For each sample, $30 \mu \mathrm{L}$ of total proteins were separated by $10 \%$ SDS-PAGE. After electrophoresis, proteins were transferred onto nitrocellulose membrane. The homogeny of loaded amounts and transfer efficiency were confirmed by Ponceau $S$ staining of nitrocellulose membranes for each experiment. Non specific binding sites were blocked in TNT buffer ( $5 \mathrm{mM}$ Tris- $\mathrm{HCl}, 15 \mathrm{mM}$ $\mathrm{NaCl}, 0.1 \%$ Tween 20) with $5 \%$ non-fat powder milk and incubated with the primary antibodies diluted in blocking solution overnight at $4{ }^{\circ} \mathrm{C}$. The rabbit monoclonal antibodies anti-EGR1 (SC-189, Santa Cruz Biotechnology, USA) and anti-phospho-p44/42 MAPK 
(ERK1/2) (Thr 202/Tyr 204) (Cell Signaling Technology/Ozyme, Saint-Quentin en Yvelines, France) were diluted at 1:1000. Total ERKs were detected using a rabbit monoclonal antip44/42 MAPK (ERK1/2) antibody (Cell Signaling Technology) at 1:5000 in blocking solution. The rabbit polyclonal antibody anti-actin was used diluted at 1:3000.

Next, the membranes were washed 3 times with TNT and incubated for 2 hours with a peroxidase-linked secondary antibody (Santa Cruz Technology) at room temperature. After 3 washings with TNT, the membranes were developed with ECL detection reagent using chemiluminescence (Amersham, Orsay, France). After Phospho-p44/42 MAPK analysis, the blots were stripped and reprobed with anti-p44/42 MAPK antibody.

\subsection{Immunocytochemistry}

MCF7 cells $\left(1.45 \times 10^{5}\right)$ were seeded on glass coverslips and grown in their medium as described before. Cells were treated with TGZ or DMSO for 3 hours in phenol red-free DMEM containing 1\% FCS. At the end of treatment, coverslips were washed with PBS and fixed in 4\% paraformaldehyde (Sigma-Aldrich) for 15 minutes. After washing in PBS, preparations were permeabilized for 10 minutes in $0.5 \%$ Triton X100. After washing in PBS, non specific binding was blocked by incubation for 30 minutes in a blocking solution (4\% bovine serum albumin, $0.1 \%$ Triton X100 in PBS Buffer). Samples were incubated with the anti-EGR1 antibody (SC-189, Santa Cruz Biotechnology) diluted at 1:400 in the blocking solution for 1 hour. They were then washed 3 times in the blocking solution and exposed for 1 hour to Alexa Fluor 555 goat anti-mouse IgG antibody (Invitrogen) diluted 1:1000 in the blocking solution. Finally, cells were rinsed with PBS 0.1\% Triton X100 for 15 minutes and cells were counterstained with Hoechst dye to visualize nuclei. Fluorescence labelling was observed under an Eclipse 80i microscope (Nikon, Champigny sur Marne, France). Images were collected using LuciaG software 4.81 (Laboratory imaging/Nikon). 


\subsection{Intracellular calcium imaging}

MCF7 cells were seeded on glass coverslips as described above. The cytoplasmic $\mathrm{Ca}^{2+}$ concentration was detected by the ratiometric fluorescent probe Fura-2. Cells were loaded with $5 \mu \mathrm{M}$ of the cell-permeant precursor Fura-2 acetoxymethyl ester (Fura-2/AM; Molecular Probes Invitrogen) in presence of pluronic F-127. After 1 hour incubation, they were washed three times with the recording saline solution containing (in $\mathrm{mM}$ ): $\mathrm{NaCl}, 120 ; \mathrm{KCl}, 5 ; \mathrm{CaCl}_{2}$, 2; $\mathrm{MgCl}_{2}, 2$; D-glucose, 10; and Hepes, 20; $\mathrm{pH}$ 7.3. Fluorescence measurements were performed on an inverted microscope (Axiovert 35; Zeiss, Germany) with an oil-immersion $\times 40$ Nikon objective (Fluor 40, NA 1.30) and a cooled CCD camera (CoolSnap HQ; Photometrics, USA). The Imaging Workbench 4.0 software (Axon Instruments, USA) was used for image acquisition and analysis. Fluorescence was excited alternately at 350 and 380 nm with a Lambda-10 filter wheel (Sutter Instrument, USA), and emitted light was collected above $520 \mathrm{~nm}$. Pairs of images were acquired every 2 seconds. Intracellular calcium was expressed throughout as the fluorescence ratio $\mathrm{F}_{350} / \mathrm{F}_{380}$, calculated after background subtraction. Experiments were performed at room temperature $\left(25-30^{\circ} \mathrm{C}\right)$. During calcium measurements, the cells were continuously superfused with saline solution: the whole dish by a bath perfusion of control medium and the recorded field by a single-tip multichannel gravity-fed system, allowing switching between various solutions. All drugs were prepared at the indicated concentrations in saline solution.

\subsection{Cell proliferation assay}

$48 \mathrm{~h}$ after siRNA transfection, the medium was replaced by DMEM supplemented with $1 \%$ FCS and $2 \mathrm{mM} \mathrm{L-glutamine.} \mathrm{After} 4 \mathrm{~h}$, cells were treated for $24 \mathrm{~h}$ with $15 \mu \mathrm{M} \Delta 2$ - 
TGZ in DMEM supplemented with 0\% FCS and $2 \mathrm{mM}$ L-glutamine. Control wells received $0.05 \%$ DMSO. At the end of the treatment, cells were washed with PBS, trypsinized and counted with the CellTiter-Glo ${ }^{\mathrm{TM}}$ Luminescent Cell Viability Assay (Promega, Charbonnieres, France). Each treatment was performed five times. 


\section{Results}

\subsection{Troglitazone induces early EGR1 expression in MCF7 breast cancer cells}

Exposure of the estrogen-dependent human breast cancer epithelial cell line MCF7 to $25 \mu \mathrm{M}$ TGZ induced a transient expression of EGRI mRNA which appeared at 30 minutes, peaked at 3 hours and then decreased (Fig. 1A). The vehicle DMSO $(0.05 \%)$ did not induce a significant increase in EGRl mRNA expression compared to the non-treated sample (Fig. 1A). Furthermore, TGZ stimulated EGRI mRNA expression in a dose-dependent manner with a better response observed at $25 \mu \mathrm{M}$ than $5 \mu \mathrm{M}$ (Fig. 1B). At the protein level, EGR1 was also stimulated with a maximum in nuclear extracts of cells that had been exposed to $25 \mu \mathrm{M}$ TGZ for 3 hours (Fig. 1C). Fetal calf serum (FCS) used as a positive control induced a higher and earlier stimulation of EGR1 (Fig. 1C). Ponceau S protein staining of membranes after transfer confirmed equivalence of loaded samples (not shown). In immunocytochemistry experiments, we observed a nuclear staining with the anti-EGR1 antibody in cells exposed for 3 hours to 25 $\mu \mathrm{M}$ TGZ. However, all the cells did not display the same staining intensity which varies from faint to intense (Fig 1D). In MCF7 cells exposed for 3 hours to 20\% FCS, the nuclear staining intensities were higher, that was in accordance with the results of western blot analyses. Staining intensity was not homogeneous between cells, as previously described.

In order to confirm the activation of the EGR1 pathway in cells exposed to TGZ, we analyzed the EGR1 target gene NAB2. NAB2 mRNA was constitutively expressed in MCF7 cells (Fig. 1E). $25 \mu \mathrm{M}$ TGZ induced a transient expression of $N A B 2$ mRNA which appeared at 6 hours, peaked at 9 hours and then decreased (Fig. 1E). The vehicle DMSO $(0.05 \%)$ did not induce a significant increase in $N A B 2$ mRNA expression compared to the non-treated sample (Fig. 1E). 


\subsection{EGR1 induction by troglitazone, ciglitazone and $15 d-P G J_{2}$ is PPAR $\gamma$ - independent}

Other PPAR $\gamma$ ligands were tested. Both CGZ and $15 \mathrm{~d}-\mathrm{PGJ}_{2}(25 \mu \mathrm{M})$ were able to induce a transient expression of EGR1 mRNA with a peak of expression observed after 3 hours of treatment (Fig. 2A). The transcription of EGR1 was followed by translation of EGR1 and by $N A B 2$ stimulation (Fig. 2B and C). In contrast, these events were not observed after 25 $\mu \mathrm{M}$ RGZ treatment (Fig. 2A-B). Since RGZ is a more potent PPAR $\gamma$ agonist than TGZ, CGZ or $15 \mathrm{~d}-\mathrm{PGJ}_{2}$, it suggested that the induction of EGRI expression required a PPAR $\gamma$ independent mechanism.

It was demonstrated by three different complementary approaches. In MCF7 cells co-treated for 3 hours with $25 \mu \mathrm{M}$ TGZ, CGZ or $15 \mathrm{~d}-\mathrm{PGJ}_{2}$ and the irreversible PPAR $\gamma$ antagonist GW9662 (5 or $25 \mu \mathrm{M})$ EGR1 mRNA expression was still stimulated (Fig. 3A). When TGZ $(25 \mu \mathrm{M})$ was tested on PPAR $\gamma$ siRNA transfected MCF7 cells (in which PPAR $\gamma$ mRNA level was decreased by more than $80 \%$ ), the induction of EGRI mRNA expression was still induced after 3 hours of treatment (Fig. 3B). Besides, MCF7 cells that were treated for 3 hours with $25 \mu \mathrm{M} \Delta 2$-TGZ, a TGZ derivative devoid of PPAR $\gamma$ agonist activity, displayed an increas in $E G R 1$ and $N A B 2$ mRNA levels (Fig. 3C). Such a $\triangle 2$-TGZ treatment was also able to induce the expression of EGR1 protein (Fig. 3D).

\subsection{Troglitazone, ciglitazone and $15 \mathrm{~d}-\mathbf{P G} \mathrm{J}_{2}$ rapidly activate ERK1/2 pathway}

We studied if the extracellular signal-regulated kinase (ERK) 1/2 pathway could be involved in EGR1 expression stimulation. TGZ, CGZ and 15d-PGJ $2(25 \mu \mathrm{M})$ induced ERK1/2 phosphorylation that could be detected as soon as 5 minutes after stimulation (Fig. 4A). The signal intensity increased between 15 and 45 minutes following treatment and decreased thereafter (Fig. 4A). In case of $\Delta 2$-TGZ $(25 \mu \mathrm{M})$ treatment, ERK1/2 
phosphorylation occurred more slowly: it was detected 15 minutes after stimulation and increased up to 75 minutes (Fig. 4B). In contrast to these compounds, RGZ induced no change in ERK1/2 phosphorylation (data not shown).

In MCF7 cells that were pretreated for 30 minutes with the MEK1/2 inhibitor U0126 (5 $\mu \mathrm{M})$ and subsequently treated with vehicle or $25 \mu \mathrm{M}$ TGZ, CGZ, $15 \mathrm{~d}-\mathrm{PGJ}_{2}$ (15 minutes) and $\Delta 2$ TGZ (30 minutes), no activated ERK1/2 was found (Fig. 4C). At a concentration as low as 5 $\mu \mathrm{M}, \mathrm{U} 0126$ was efficient to inhibit the EGR1 expression usually induced by TGZ, CGZ, 15d$\mathrm{PGJ}_{2}$ (Fig. 4D). In case of $\triangle 2$-TGZ treatment, U0126 inhibited EGRI mRNA induction partially at $5 \mu \mathrm{M}$ whereas a complete inhibition was observed at $25 \mu \mathrm{M}$ (Fig. 4D). The MAPK inhibitor was also able to inhibit the TGZ-induced increase in EGR1 protein (Fig. 4E). To determine the role of the other MAP Kinases on the regulation of EGR1 expression, cells were treated with $\Delta 2$-TGZ in the presence of $10 \mu \mathrm{M}$ of a specific inhibitor of p38 MAPK (SB203580) (Fig. 5A) and JNK (SP600125) (Fig. 5B). In contrast to U0126 that completely abolished EGR1 expression, neither SB20358 nor SP600125 could antagonize this response to $\Delta 2$-TGZ (Fig. 5A and B).

\subsection{PPAR $\gamma$-independent expression of EGR1 does not require EGFR activation}

We tested the possibility for EGFR to be involved in the PPAR $\gamma$-independent activation of EGR1 in MCF7 cells. For this purpose, we used the EGFR tyrosine kinase inhibitors PD153035 or AG1478. At $5 \mu \mathrm{M}$, these compounds totally inhibited ERK1/2 phosphorylation in MCF7 cells exposed to EGF (15 nM for 5 minutes) (Fig. 6A). We also observed that the exposure to EGF ( $15 \mathrm{nM})$ for 1 hour could increase EGRI mRNA level in MCF7 cells and that this effect did not occur in the presence of the EGFR antagonists (Fig. 6B). However, in our conditions, $\triangle 2$-TGZ-induced EGR1 mRNA expression was not blocked by the two EGFR tyrosine kinase inhibitors AG1478 and PD153035 (Fig. 6C). Our study 
performed in MCF7 cells transfected with siRNA targeting EGFR confirmed the absence of a role of EGFR in the induction of EGRI mRNA expression and ERK phosphorylation after $\Delta 2$-TGZ treatment (Fig. 6D).

\subsection{PPAR $\gamma$-independent expression of EGR1 in MDA-MB-231 cells}

In order to determine whether the PPAR $\gamma$-independent expression of EGR1 expression could be observed in other breast cancer cells, we studied its expression in the hormoneindependent cell line MDA-MB-231. After 3 hours of treatment, $\Delta 2$-TGZ was able to induce EGRI mRNA expression (Fig. 7). Then, we investigated whether the ERK1/2 pathway was involved in this event. A pretreatment with the ERK1/2 inhibitor U0126 (5 $\mu \mathrm{M})$ abolished EGR1 mRNA expression induced by $\triangle 2$-TGZ in MDA-MB-231 cells (Fig. 7). In contrast, the EGFR inhibitor AG1478 had no effect (Fig. 7). Thus, the PPAR $\gamma$-independent expression of EGR1 is not restricted to MCF7 cells.

\subsection{PPAR $\gamma$-independent expression of EGR1 is mediated by $\mathrm{Ca}^{2+}$}

In order to determine whether calcium signaling could be involved in the PPAR $\gamma$ independent ERK1/2-mediated induction of EGR1 expression, MCF7 cells were pretreated for 30 minutes with the $\mathrm{Ca}^{2+}$ chelator BAPTA-AM before their exposure to PPAR $\gamma$ ligands $(25 \mu \mathrm{M})$. This treatment abolished the usual increase in EGRI mRNA level (Fig. 8A). ERK1/2 could not be activated in these conditions (Fig. 8A). Interestingly, we observed that in MCF7 cells, the $\mathrm{Ca}^{2+}$ ionophore A23187 also induced EGRI mRNA expression but with an earlier response than those usually observed with $\Delta 2$-TGZ (Fig. 8B). Moreover, A23187 treatment also induced ERK1/2 activation before $E G R 1 \mathrm{mRNA}$ expression ( 2 minutes versus 15 minutes respectively) (Fig. 8C). This A23187-triggered EGRl induction was prevented in 
the presence of the antagonist U0126 which also inhibited ERK1/2 phosphorylation (data not shown).

Then, we studied intracellular $\mathrm{Ca}^{2+}$ in MCF7 cells (Fig. 8D). In control cells exposed to DMSO no change in the basal level of $\mathrm{Ca}^{2+}$ was observed. In contrast, MCF7 cells exposed for 2 minutes to $25 \mu \mathrm{M}$ TGZ showed a fast increase in intracellular calcium, $\left[\mathrm{Ca}^{2+}\right]_{\mathrm{i}}$, which disappeared as soon as cells were back in TGZ-free medium (Fig. 8D, upper panel). After recovery to basal level, a new exposure to TGZ induced again a rise in $\left[\mathrm{Ca}^{2+}\right]_{\mathrm{i}}$. An increase in $\left[\mathrm{Ca}^{2+}\right]_{\mathrm{i}}$ was also observed in response to $25 \mu \mathrm{M} \Delta 2$-TGZ, showing that the calcium increase observed with TGZ was a PPAR $\gamma$-independent event (Fig. 8D, middle panel). However, after elimination of $\Delta 2$-TGZ, cytosolic calcium decreased more slowly than after TGZ treatment. This rise in $\left[\mathrm{Ca}^{2+}\right]_{\mathrm{i}}$ did not occur in the presence of BAPTA-AM but it was still observed when $\Delta 2$-TGZ was applied in a $\mathrm{Ca}^{2+}$-free solution suggesting that a release from intracellular stores was involved, rather than an influx of external $\mathrm{Ca}^{2+}$ (Fig. 8D, middle and lower panels).

\subsection{EGR1 is a mediator of $\Delta 2$-TGZ-induced growth arrest}

To test whether EGR1 is critical for the antiproliferative action of $\Delta 2$-TGZ, we performed gene silencing in MCF7 cells. The suppression of EGR1 expression was confirmed by RT-PCR (Fig. 9A). In each experiment, at least $50 \%$ of EGRl mRNA expression was observed. In MCF7 cells transfected with Ctrl siRNA, after $24 \mathrm{~h}$ treatment with $15 \mu \mathrm{M} \Delta 2$ TGZ, the number of viable cells was $47 \%$ of those exposed to DMSO. When the cells were transfected with the EGRI siRNA, $\triangle 2$-TGZ affected less efficiently MCF7 cells since viable cells were $61 \%$ of those exposed to DMSO (Fig. 9B). 


\section{Discussion}

In this study, we show that EGRl is an early target gene of TGZ in MCF7 cells with a peak of expression after 3 hours of treatment. Such a transient induction of EGR1 expression was also observed in response to $\mathrm{CGZ}$ and $15 \mathrm{~d}-\mathrm{PGJ} \mathrm{J}_{2}$. The expression of EGR1 protein was confirmed by Western blotting and by the delayed induction of $N A B 2$, a well known EGR1 target gene [21]. EGR1 could be a mediator of PPAR $\gamma$ ligand action since a transient stimulation of its expression has also been reported in other cell lines like human colorectal carcinoma cells HCT116 or activated T cells in response to TGZ or $15 \mathrm{~d}_{-} \mathrm{PGJ} \mathrm{J}_{2}$ respectively [10, 22].

Our results demonstrate that EGR1 expression is stimulated in breast cancer cell lines in a PPAR $\gamma$-independent manner. This was first suggested by the fact that RGZ was not able to induce EGR1 expression although it was the most potent PPAR $\gamma$ agonist tested [10]. We confirmed the PPAR $\gamma$-independent mechanism by the use of the PPAR $\gamma$ antagonist GW9662 and PPAR $\gamma$ silencing. Furthermore, the TGZ inactive derivative $\Delta 2-\mathrm{TGZ}$ was also able to stimulate EGR1 expression after 3 hours of treatment in both hormone-dependent (MCF7) and hormone-independent (MDA-MB-231) breast cancer cells. These results are consistent with data obtained in human colorectal carcinoma cells HCT116 [13]. Thus, EGR1 expression can be added to the increasing list of PPAR $\gamma$-independent effects of thiazolidinediones observed in cancer cell lines [9].

The activation of the MEK/ERK/ELK cascade is the classical pathway essential for enhanced EGR1 biosynthesis [23]. In MCF7 cells, we clearly demonstrated that a transient phosphorylation of ERK1/2 occurred early after TGZ, CGZ and $15 \mathrm{~d}-\mathrm{PGJ}_{2}$ treatment whereas no change in ERK phosphorylation was observed in response to RGZ. A similar effect of 
TGZ was previously described in MCF7 cells [24, 25], in porcine endothelial cells [26], and in the rat liver epithelial cell line GN4 $[27,28]$. In GN4 cells, the phosphorylation of ERK was also stimulated by CGZ [27]. Consistent with our data, in astrocytes, CGZ and $15 \mathrm{~d}-\mathrm{PGJ} \mathrm{J}_{2}$ stimulated ERK phosphorylation whereas RGZ was inefficient [29]. Interestingly, we found that ERK1/2 phosphorylation was also stimulated by $\Delta 2$-TGZ, demonstrating that it was a PPAR $\gamma$-independent event. This was previously reported in astrocytes not only with $\triangle 2$-TGZ but also with $\triangle 2$-CGZ [27]. We further show that this early activation is essential for EGR1 induction in MCF7 and MDA-MB-231 cells by the use of the MEK inhibitor U0126, like in HCT116 cells [13].

In parallel to ERK activation, thiazolidinediones are able to induce various MAPKs in different cell models [30]. For instance, in MCF7 cells, TGZ and TZD18 also activate p38 and c-jun N-terminal kinase (JNK) pathways [25, 31]. However, concerning the regulation of EGR1 expression in MCF7 cells exposed to $\triangle 2$-TGZ, p38 and JNK pathways are likely not involved. Indeed, ERK1/2 phosphorylation inhibition is sufficient to completely block EGR1 synthesis whereas JNK and p38 inhibitors have no effect. Consistent with our data, the p38 MAPK inhibitor PD169316 did not prevent EGRl induction by the retinoid AHPN in human lung carcinoma cells [32]. Similarly, in intestinal epithelial cells U0126 was able to block EGR1 expression induced by sulindac sulfide whereas SP600125 and SB203580 were inefficient [33].

Previous studies suggested a connection between the EGFR and MAPK signaling by PPAR $\alpha$ and PPAR $\gamma$ ligands [24, 34-36]. MCF7 and MDA-MB-231 cells expressed significant levels of EGFR protein [37]. However, in our study, although the EGFR antagonists AG1478 and PD153035 inhibited efficiently EGF-stimulated ERK phosphorylation and EGR1 expression, they did not affect the stimulation of EGR1 expression in case of $\Delta 2$-TGZ 
treatment. Similarly, TGZ did not induce EGFR activation in rat liver epithelial cells GN4 [36].

MAPK phosphorylation is also often associated with an increase in $\left[\mathrm{Ca}^{2+}\right]_{\mathrm{i}}$. The $\mathrm{Ca}^{2+}-$ regulated protein kinase $\mathrm{C}$ can activate ERK through a RAF-dependent mechanism. Interestingly, TGZ and CGZ were shown to increase $\left[\mathrm{Ca}^{2+}\right]_{\mathrm{i}}$ in mouse ES cells, in rat liver epithelial cells GN4 as well as in normal urothelial cells [28, 38, 39]. In MCF7 cells, we show that TGZ triggers an immediate increase in cytosolic $\mathrm{Ca}^{2+}$ and that this event is also obtained in response to the PPAR $\gamma$-inactive compound $\Delta 2$-TGZ. This result is in accordance with the fact that both TGZ and CGZ trigger an increase in $\left[\mathrm{Ca}^{2+}\right]_{i}$ not only in PPAR $\gamma^{+/+}$but also in PPAR $\gamma^{-1-}$ mouse ES cells [38]. Moreover, we show for the first time that $\mathrm{Ca}^{2+}$ is essential for the activation of ERK1/2 and the expression of EGR1 by $\Delta 2-\mathrm{TGZ}, \mathrm{TGZ}, \mathrm{CGZ}$, or $15 \mathrm{~d}-\mathrm{PGJ}_{2}$ in MCF7 cells and MDA-MB-231. Interestingly, biosynthesis of EGR1 in MIN6 insulinoma cells treated with glucose, tolbutamide or $\mathrm{KCl}$ requires an elevation of $\mathrm{Ca}^{2+}$ [40].

We further observed that the increase in cytosolic $\mathrm{Ca}^{2+}$ occurred even when MCF7 cells were superfused in a $\mathrm{Ca}^{2+}$-free solution containing EGTA, demonstrating liberation from intracellular stores rather than an influx from extracellular medium. This is in accordance with the effects described previously for TGZ and CGZ in mouse ES cells [38].

The roles of EGR1 in cancer development and response to therapies are ambiguous since EGR1 may either inhibit or stimulate cell growth depending on the stimulus and the cellular context. Many observations support the notion that EGR1 contributes to prostate cancer progression. The EGRl mRNA is highly expressed in prostate adenocarcinoma, compared with normal tissues [41]. In contrast, EGRl expression is absent or very weak in several human breast cancer cell lines and tissues compared to normal cells or tissues $[17,18]$. 
We confirmed these data in the two breast cancer cell lines MCF7 and MDA-MB-231. We further show that induction of EGRI expression is partly involved in the anti-proliferative action of the thiazolidinedione $\triangle 2$-TGZ. Indeed, EGRl depletion reduced by $14 \%$ the antiproliferative activity of $\triangle 2-\mathrm{TGZ}$ on MCF7 cells. Similarly to our results, cellular sensibility to different therapeutic agents is modified after EGRl interference. For example, EGRl siRNA decreases the tolfenamic acid-induced apoptosis in the colorectal carcinoma cell line HCT-116 [42]. EGRI siRNA lowers by $15 \%$ cell death-induced by etoposide in osteosarcoma cells U2OS [43].

Concerning the events downstream of EGR1, it might be interesting to address the involvement of HSP70 and NF-кB. Indeed, in lung fibroblasts, cigarette smoke water extracts induce an EGR1-dependent expression of HSP70 [44]. The latter can block the activation of the transcription factor NFkB which is antiproliferative [45]. Moreover, the suppression of $\mathrm{NF}-\kappa \mathrm{B}$ is involved in TGZ-induced inhibition of colon cancer cell growth [46].

Besides, EGR1 induction was reported to occur in mouse embryonic fibroblasts exposed to the endoplasmic reticulum (ER)-stress inducer thapsigargin [47]. EGR1 was also shown to play a role in thapsigargin-induced apoptosis in the melanoma cell line A375-C6 [48]. Since some PPAR $\gamma$ ligands are known to trigger ER stress in breast cancer cell lines, the involvement of EGR1 in the ER stress in breast cancer cells could be considered [31].

In summary, we provide evidence that TGZ, CGZ and $15 \mathrm{~d}-\mathrm{PGJ}_{2}$ stimulate an early expression of EGR1 in breast cancer cells in a PPAR $\gamma$-independent manner. This event requires a rise in $\left[\mathrm{Ca}^{2+}\right]_{i}$, and the subsequent activation of ERK1/2 signaling pathway. We also show that EGR1 participates in the PPAR $\gamma$-independent antiproliferative action. It will be 
interesting to determine if thiazolidinediones also activate the $\mathrm{Ca}^{2+} / \mathrm{ERK} / \mathrm{EGR} 1$ pathway in non cancerous mammary epithelial cells or if this event is restricted to cancer cells.

\section{Acknowledgments}

We would like to thank SANOFI-AVENTIS for a studentship to Stéphane Salamone. We acknowledge Martine Chillet, Alexandra Kleinclauss, Brigitte Fernette, Sandrine Adach and François Dupire for technical assistance.

\section{References}

[1] Michalik L, Auwerx J, Berger JP, Chatterjee VK, Glass CK, Gonzalez FJ, et al. International Union of Pharmacology. LXI. Peroxisome proliferator-activated receptors. Pharmacol Rev 2006; 58: 726-41.

[2] Cheatham WW. Peroxisome proliferator-activated receptor translational research and clinical experience. Am J Clin Nutr 2010; 91: 262S-266S.

[3] Blanquicett C, Roman J, Hart CM. Thiazolidinediones as anti-cancer agents. Cancer Ther 2008; 6: 25-34.

[4] Koeffler HP. Peroxisome proliferator-activated receptor gamma and cancers. Clin Cancer Res 2003; 9: 1-9.

[5] Fenner MH, Elstner E. Peroxisome proliferator-activated receptor-gamma ligands for the treatment of breast cancer. Expert Opin Investig Drugs 2005; 14: 557-68.

[6] Kim KY, Kim SS, Cheon HG. Differential anti-proliferative actions of peroxisome proliferator-activated receptor-gamma agonists in MCF-7 breast cancer cells. Biochem Pharmacol 2006; 72: 530-40. 
[7] Kar R, Singha PK, Venkatachalam MA, Saikumar P. A novel role for MAP1 LC3 in nonautophagic cytoplasmic vacuolation death of cancer cells. Oncogene 2009; 28: 2556-68.

[8] Zhou J, Zhang W, Liang B, Casimiro MC, Whitaker-Menezes D, Wang M, et al. PPARgamma activation induces autophagy in breast cancer cells. Int $\mathbf{J}$ Biochem Cell Biol 2009; 41: 2334-42.

[9] Wei S, Yang J, Lee SL, Kulp SK, Chen CS. PPARgamma-independent antitumor effects of thiazolidinediones. Cancer Lett 2009; 276: 119-24.

[10] Lecomte J, Flament S, Salamone S, Boisbrun M, Mazerbourg S, Chapleur Y, et al. Disruption of ERalpha signalling pathway by PPARgamma agonists: evidences of PPARgamma-independent events in two hormone-dependent breast cancer cell lines. Breast Cancer Res Treat 2008; 112: 437-51.

[11] Huang JW, Shiau CW, Yang YT, Kulp SK, Chen KF, Brueggemeier RW, et al. Peroxisome proliferator-activated receptor gamma-independent ablation of cyclin D1 by thiazolidinediones and their derivatives in breast cancer cells. Mol Pharmacol 2005; 67: 13428.

[12] Colin C, Salamone S, Grillier-Vuissoz I, Boisbrun M, Kuntz S, Lecomte J, et al. New troglitazone derivatives devoid of PPARgamma agonist activity display an increased antiproliferative effect in both hormone-dependent and hormone-independent breast cancer cell lines. Breast Cancer Res Treat 2010; 124: 101-10.

[13] Baek SJ, Wilson LC, Hsi LC, Eling TE. Troglitazone, a peroxisome proliferatoractivated receptor gamma (PPAR gamma ) ligand, selectively induces the early growth response-1 gene independently of PPAR gamma. A novel mechanism for its anti-tumorigenic activity. J Biol Chem 2003; 278: 5845-53. 
[14] Sukhatme VP, Cao XM, Chang LC, Tsai-Morris CH, Stamenkovich D, Ferreira PC, et al. A zinc finger-encoding gene coregulated with c-fos during growth and differentiation, and after cellular depolarization. Cell 1988; 53: 37-43.

[15] Swirnoff AH, Milbrandt J. DNA-binding specificity of NGFI-A and related zinc finger transcription factors. Mol Cell Biol 1995; 15: 2275-87.

[16] Baron V, De Gregorio G, Krones-Herzig A, Virolle T, Calogero A, Urcis R, et al. Inhibition of Egr-1 expression reverses transformation of prostate cancer cells in vitro and in vivo. Oncogene 2003; 22: 4194-204.

[17] Huang JW, Shiau CW, Yang J, Wang DS, Chiu HC, Chen CY, et al. Development of small-molecule cyclin D1-ablative agents. J Med Chem 2006; 49: 4684-9.

[18] Liu J, Liu YG, Huang R, Yao C, Li S, Yang W, et al. Concurrent down-regulation of Egr-1 and gelsolin in the majority of human breast cancer cells. Cancer Genomics Proteomics 2007; 4: 377-85.

[19] Huang RP, Liu C, Fan Y, Mercola D, Adamson ED. Egr-1 negatively regulates human tumor cell growth via the DNA-binding domain. Cancer Res 1995; 55: 5054-62.

[20] Boschi D, Tron GC, Lazzarato L, Chegaev K, Cena C, Di Stilo A, et al. NO-donor phenols: a new class of products endowed with antioxidant and vasodilator properties. J Med Chem 2006; 49: 2886-97.

[21] Kumbrink J, Gerlinger M, Johnson JP. Egr-1 induces the expression of its corepressor nab2 by activation of the nab2 promoter thereby establishing a negative feedback loop. J Biol Chem 2005; 280: 42785-93.

[22] Cippitelli M, Fionda C, Di Bona D, Lupo A, Piccoli M, Frati L, et al. The cyclopentenone-type prostaglandin 15-deoxy-delta 12,14-prostaglandin J2 inhibits CD95 ligand gene expression in $\mathrm{T}$ lymphocytes: interference with promoter activation via 
peroxisome proliferator-activated receptor-gamma-independent mechanisms. J Immunol 2003; 170: 4578-92.

[23] Thiel G, Cibelli G. Regulation of life and death by the zinc finger transcription factor Egr-1. J Cell Physiol 2002; 193: 287-92.

[24] Friday E, Oliver R, 3rd, Welbourne T, Turturro F. Role of epidermal growth factor receptor (EGFR)-signaling versus cellular acidosis via $\mathrm{Na}+\mathrm{H}+$ exchanger1(NHE1)-inhibition in troglitazone-induced growth arrest of breast cancer-derived cells MCF-7. Cell Physiol Biochem 2007; 20: 751-62.

[25] Yin F, Bruemmer D, Blaschke F, Hsueh WA, Law RE, Herle AJ. Signaling pathways involved in induction of GADD45 gene expression and apoptosis by troglitazone in human MCF-7 breast carcinoma cells. Oncogene 2004; 23: 4614-23.

[26] Li X, Yang X, Xu Y, Jiang X, Nan F, Tang H. Troglitazone inhibits cell proliferation by attenuation of epidermal growth factor receptor signaling independent of peroxisome proliferator-activated receptor gamma. Cell Res 2009; 19: 720-32.

[27] Gardner OS, Shiau CW, Chen CS, Graves LM. Peroxisome proliferator-activated receptor gamma-independent activation of p38 MAPK by thiazolidinediones involves calcium/calmodulin-dependent protein kinase II and protein kinase R: correlation with endoplasmic reticulum stress. J Biol Chem 2005; 280: 10109-18.

[28] Dewar BJ, Gardner OS, Chen CS, Earp HS, Samet JM, Graves LM. Capacitative calcium entry contributes to the differential transactivation of the epidermal growth factor receptor in response to thiazolidinediones. Mol Pharmacol 2007; 72: 1146-56.

[29] Lennon AM, Ramauge M, Dessouroux A, Pierre M. MAP kinase cascades are activated in astrocytes and preadipocytes by 15-deoxy-Delta(12-14)-prostaglandin $\mathrm{J}(2)$ and the thiazolidinedione ciglitazone through peroxisome proliferator activator receptor gamma- 
independent mechanisms involving reactive oxygenated species. J Biol Chem 2002; 277: 29681-5.

[30] Gardner OS, Dewar BJ, Graves LM. Activation of mitogen-activated protein kinases by peroxisome proliferator-activated receptor ligands: an example of nongenomic signaling. Mol Pharmacol 2005; 68: 933-41.

[31] Zang C, Liu H, Bertz J, Possinger K, Koeffler HP, Elstner E, et al. Induction of endoplasmic reticulum stress response by TZD18, a novel dual ligand for peroxisome proliferator-activated receptor alpha/gamma, in human breast cancer cells. Mol Cancer Ther 2009; 8: 2296-307.

[32] Sakaue M, Adachi H, Dawson M, Jetten AM. Induction of Egr-1 expression by the retinoid AHPN in human lung carcinoma cells is dependent on activated ERK1/2. Cell Death Differ 2001; 8: 411-24.

[33] Moon Y, Yang H, Kim YB. Up-regulation of early growth response gene 1 (EGR-1) via ERK1/2 signals attenuates sulindac sulfide-mediated cytotoxicity in the human intestinal epithelial cells. Toxicol Appl Pharmacol 2007; 223: 155-63.

[34] Orellana A, Holuigue L, Hidalgo PC, Faundez V, Gonzalez A, Bronfman M. Ciprofibrate, a carcinogenic peroxisome proliferator, increases the phosphorylation of epidermal-growth-factor receptor in isolated rat hepatocytes. Eur J Biochem 1993; 215: 903-6. [35] Pauley CJ, Ledwith BJ, Kaplanski C. Peroxisome proliferators activate growth regulatory pathways largely via peroxisome proliferator-activated receptor alpha-independent mechanisms. Cell Signal 2002; 14: 351-8.

[36] Gardner OS, Dewar BJ, Earp HS, Samet JM, Graves LM. Dependence of peroxisome proliferator-activated receptor ligand-induced mitogen-activated protein kinase signaling on epidermal growth factor receptor transactivation. J Biol Chem 2003; 278: 46261-9. 
[37] Subik K, Lee JF, Baxter L, Strzepek T, Costello D, Crowley P, et al. The expression patterns of eR, pR, HeR2, cK5/6, eGFR, Ki-67 and AR by immunohistochemical analysis in breast cancer cell Lines. Breast Cancer: Basic and Clinical Research 2010; 4: 35-41.

[38] Palakurthi SS, Aktas H, Grubissich LM, Mortensen RM, Halperin JA. Anticancer effects of thiazolidinediones are independent of peroxisome proliferator-activated receptor gamma and mediated by inhibition of translation initiation. Cancer Res 2001; 61: 6213-8.

[39] Chopra B, Georgopoulos NT, Nicholl A, Hinley J, Oleksiewicz MB, Southgate J. Structurally diverse peroxisome proliferator-activated receptor agonists induce apoptosis in human uro-epithelial cells by a receptor-independent mechanism involving store-operated calcium channels. Cell Prolif 2009; 42: 688-700.

[40] Mayer SI, Thiel G. Calcium influx into MIN6 insulinoma cells induces expression of Egr-1 involving extracellular signal-regulated protein kinase and the transcription factors Elk1 and CREB. Eur J Cell Biol 2009; 88: 19-33.

[41] Gitenay D, Baron VT. Is EGR1 a potential target for prostate cancer therapy? Future Oncol 2009; 5: 993-1003.

[42] Lee SH, Bahn JH, Choi CK, Whitlock NC, English AE, Safe S, et al. ESE-1/EGR-1 pathway plays a role in tolfenamic acid-induced apoptosis in colorectal cancer cells. Mol Cancer Ther 2008; 7: 3739-50.

[43] Yu J, Baron V, Mercola D, Mustelin T, Adamson ED. A network of p73, p53 and Egr1 is required for efficient apoptosis in tumor cells. Cell Death Differ 2007; 14: 436-46.

[44] Li CJ, Ning W, Matthay MA, Feghali-Bostwick CA, Choi AM. MAPK pathway mediates EGR-1-HSP70-dependent cigarette smoke-induced chemokine production. Am J Physiol Lung Cell Mol Physiol 2007; 292: L1297-303. 
[45] Gutierrez LL, Maslinkiewicz A, Curi R,de Bittencourt PI, Jr. Atherosclerosis: a redoxsensitive lipid imbalance suppressible by cyclopentenone prostaglandins. Biochem Pharmacol 2008; 75: 2245-62.

[46] Ban JO, Kwak DH, Oh JH, Park EJ, Cho MC, Song HS, et al. Suppression of NFkappaB and GSK-3beta is involved in colon cancer cell growth inhibition by the PPAR agonist troglitazone. Chem Biol Interact 2010; 188: 75-85.

[47] Liang SH, Zhang W, McGrath BC, Zhang P, Cavener DR. PERK (eIF2alpha kinase) is required to activate the stress-activated MAPKs and induce the expression of immediate-early genes upon disruption of ER calcium homoeostasis. Biochem J 2006; 393: 201-9.

[48] Muthukkumar S, Nair P, Sells SF, Maddiwar NG, Jacob RJ, Rangnekar VM. Role of EGR-1 in thapsigargin-inducible apoptosis in the melanoma cell line A375-C6. Mol Cell Biol 1995; 15: 6262-72.

\section{Footnotes}

${ }^{1}$ Stephane Salamone present address: Unité de Chimie des Biomolécules (URA CNRS 2128), Institut Pasteur, 75724 Paris, France. stephane.salamone@ pasteur.fr

This work was supported by grants of the "Université Henri Poincaré (BQR)", of the "Conseil Régional de Lorraine", of the "Association pour la Recherche sur le Cancer", of the "Ligue Contre le Cancer", of the "CPER" and of "FEDER". Sarra Chbicheb was recipient of a grant of the "Ministère de l'enseignement supérieur et de la recherche". Xiao Yao was recipient of a post-doctoral fellowship of the "Université Henri Poincaré and Conseil Régional de Lorraine". 


\section{Figure legends}

Fig. 1. Troglitazone induces $E G R I$ expression. A, Time-dependent induction of EGRI mRNA in MCF7 cells exposed to $25 \mu \mathrm{M}$ TGZ (T) for the indicated times. Control cells were treated with $0.05 \%$ DMSO (D) or non-treated (NT). EGR1 and the housekeeping gene $R P L P O$ mRNA expression were analyzed by RT-PCR. The amplified products were analyzed by agarose gel electrophoresis. B, Dose-dependent induction of EGR1 mRNA in MCF7 cells treated with decreasing doses of TGZ (T) for 3 hours. Control cells were treated with $0.05 \%$ DMSO (D) or non-treated (NT). EGRl mRNA was analyzed by RT-PCR and compared to the housekeeping gene RPLPO. The amplified PCR products were detected after agarose gel electrophoresis. C, Time-dependent induction of EGR1 protein $(80 \mathrm{kDa})$ in MCF7 cells exposed to $25 \mu \mathrm{M}$ TGZ (T), $0.05 \%$ DMSO (D) or $20 \%$ fetal calf serum (FCS) for the indicated times. 20\% FCS treatment was used as positive control. Nuclear extracts were prepared as described under "experimental procedures" and subjected to western blot analysis with anti-EGR1 antibody. D, Immunodetection of EGR1 (EGR1, middle panels) in MCF7 cells exposed to $25 \mu \mathrm{M}$ TGZ (T) or $20 \%$ FCS for 3 hours. Control cells were treated with $0.05 \%$ DMSO (D). The results of the counterstaining with Hoechst dye (left panels) as well as the merged pictures (right panels) are shown for each treatment. Bar represents $50 \mu \mathrm{m}$ and the magnification is identical for all pictures. E, Time-dependent induction of EGRl target gene $N A B 2$ in MCF7 cells exposed to $25 \mu \mathrm{M}$ TGZ (T) for the indicated times. Control cells were treated with $0.05 \%$ DMSO (D). $N A B 2$ and the housekeeping gene RPLPO expressions were analyzed at the mRNA level by RT-PCR. The amplified products were analyzed by agarose gel electrophoresis. 
Fig. 2. Ciglitazone and $15 \mathrm{~d}-\mathrm{PG} \mathrm{J}_{2}$ also stimulate the expression of $E G R 1$ and its target gene NAB2. A, Time-dependent induction of EGR1 mRNA in MCF7 cells exposed to $25 \mu \mathrm{M}$ CGZ (C), 15d-PGJ $2(\mathrm{P})$ and RGZ (R) for the indicated times. Control cells were treated with $0.05 \%$ DMSO (D, vehicle) or non-treated (NT). B, Induction of EGR1 protein $(80 \mathrm{kDa})$ in MCF7 cells exposed to $25 \mu \mathrm{M}$ CGZ (C), 15d-PGJ 2 (P), RGZ (R) or $0.05 \%$ DMSO (D) for 3 hours. Nuclear extracts were prepared as described under "experimental procedures" and subjected to western blot analysis using anti-EGR1 antibody. C, RT-PCR analysis of the expression of $N A B 2$ mRNA in MCF7 cells exposed for 6 and 9 hours to $25 \mu \mathrm{M}$ CGZ (C) and $15 \mathrm{~d}_{-} \mathrm{PGJ}_{2}(\mathrm{P})$, or $0.05 \%$ DMSO (D). The amplified products were detected after agarose gel electrophoresis and expressed relatively to the housekeeping gene RPLPO.

Fig. 3. EGR1 expression is independent of PPAR $\gamma$ activation. A, Absence of inhibition of EGRl induction in the presence of the PPAR $\gamma$ antagonist GW9662. MCF7 cells were pretreated with 5 or $25 \mu \mathrm{M}$ GW9662 (GW) for 30 minutes before treatment with $25 \mu \mathrm{M}$ TGZ (T), CGZ (C) or $15 \mathrm{~d}_{-}-\mathrm{PGJ}_{2}(\mathrm{P})$ for 3 hours. Control cells were treated with $0.05 \%$ DMSO (vehicle, D) or non-treated (NT). mRNA expression was analyzed by RT-PCR. B, TGZinduced expression of EGRI mRNA after silencing of PPAR $\gamma$ receptors by RNA interference. MCF7 cells were transiently transfected with double-strand siRNA targeting PPAR $\gamma$ or control (Ctrl) siRNA. 48 hours after transfection, cells were exposed to $25 \mu \mathrm{M}$ TGZ (T) or $0.05 \%$ DMSO (D) for 3 hours. C, Expression of EGRl and its target gene NAB2 following treatment with the PPAR $\gamma$ inactive analogue of TGZ, $\Delta 2$-TGZ. Cells were treated with $25 \mu \mathrm{M}$ $\Delta 2$-TGZ $(\Delta 2 \mathrm{~T})$ or $0.05 \%$ DMSO (D) for the indicated times. mRNA expression was analyzed by RT-PCR. The amplified products were detected after agarose gel electrophoresis and expressed relatively to the housekeeping gene RPLPO. D, Induction of EGR1 protein $(80 \mathrm{kDa})$ in MCF7 cells exposed to $25 \mu \mathrm{M}$ TGZ (T), its inactive analogue, $\Delta 2$-TGZ, $(\Delta 2 \mathrm{~T})$ or $0.05 \%$ 
DMSO (D) for 3 hours. Nuclear extracts were prepared as described under "experimental procedures" and subjected to western blot analysis using anti-EGR1 antibody.

Fig. 4. The induction of EGRI expression depends on the activation of the ERK1/2 pathway. A, Changes in ERK1/2 phosphorylation were assessed in MCF7 cells after $25 \mu \mathrm{M}$ TGZ (T), CGZ (C), and 15d-PGJ $2(\mathrm{P})$ treatment for the indicated times. Cells were harvested in 2X Laemmli buffer and total proteins were subjected to western blot analysis using antiphospho-ERK1/2 antibody (P-ERK1/2). The blots were stripped and reprobed using antibody directed against total ERK1/2 (ERK1/2). B, A similar experiment was done in MCF7 cells after $\Delta 2$-TGZ $(\triangle 2 \mathrm{~T})$ treatment for the indicated times. C, MCF7 cells were pretreated with 5 $\mu \mathrm{M}$ U0126, a specific inhibitor of MEK1/2, for 30 minutes before treatment with $25 \mu \mathrm{M}$ TGZ (T), CGZ (C), 15d-PGJ $2(\mathrm{P})$ for 15 minutes and $25 \mu \mathrm{M} \Delta 2$-TGZ $(\Delta 2 \mathrm{~T})$ for 30 minutes. Control cells were treated with 0.05\% DMSO (vehicle). Phospho-ERK1/2 and total ERK1/2 were analyzed by western blot. D, MCF7 cells were pretreated with 5 or $25 \mu \mathrm{M}$ U0126, a specific inhibitor of MEK1/2, for 30 minutes before treatment with $25 \mu \mathrm{M}$ TGZ (T), CGZ (C), $15 \mathrm{~d}-\mathrm{PGJ}_{2}(\mathrm{P})$ and $\Delta 2$-TGZ $(\Delta 2 \mathrm{~T})$ for 3 hours. Control cells were treated with $0.05 \%$ DMSO (vehicle) or non-treated (NT). EGRl mRNA expression was analyzed by RT-PCR. The amplified products were detected after agarose gel electrophoresis and expressed relatively to the housekeeping gene RPLPO. E, Cells were pretreated with $5 \mu \mathrm{M}$ U0126 for 30 minutes before treatment with $25 \mu \mathrm{M}$ TGZ (T) for 3 hours. Nuclear extracts were prepared as described under "experimental procedures" and subjected to western blot analysis to detect the $80 \mathrm{kDa}$ EGR1 protein. Control cells were treated with $0.05 \%$ DMSO (D, vehicle) or nontreated (NT). 
Fig. 5. The induction of $E G R 1$ expression is independent on the activation of the p38 and JNK pathways. MCF7 cells were pretreated for 30 minutes with $10 \mu \mathrm{M}$ SB203580 (A) or SP600125 (B), specific inhibitors of p38 and JNK MAPK respectively, before treatment with $25 \mu \mathrm{M} \Delta 2$-TGZ $(\Delta 2 \mathrm{~T})$ for 3 hours. Control cells were treated with $0.05 \%$ DMSO (vehicle). EGR1 mRNA expression was analyzed by RT-PCR. The amplified products were detected after agarose gel electrophoresis and expressed relatively to the housekeeping gene RPLPO.

Fig. 6. EGFR is not involved in the PPAR $\gamma$-independent expression of EGR1. A, Phospho-ERK1/2 and total ERK1/2 were analyzed by western blot. MCF7 cells were pretreated for 30 minutes with $5 \mu \mathrm{M}$ of the EGFR tyrosine kinase inhibitors PD153035 (PD) or AG1478 (AG) before treatment with 15 nM EGF for 5 minutes. Control cells were treated with $0.05 \%$ DMSO (D). B, EGR1 mRNA expression induced by EGF and effects of different EGFR inhibitors. MCF7 cells were pretreated for 30 minutes with $5 \mu \mathrm{M}$ of the EGFR tyrosine kinase inhibitors PD153035 (PD) or AG1478 (AG) before treatment with 15 nM EGF for 1 hour. Control cells were treated with $0.05 \%$ DMSO (D). mRNA expression was analyzed by RT-PCR. The amplified products were detected after agarose gel electrophoresis and expressed relatively to the housekeeping gene RPLPO. C, EGRI mRNA expression in presence of different EGFR inhibitors. MCF7 cells were pretreated for 30 minutes with $5 \mu \mathrm{M}$ of the EGFR tyrosine kinase inhibitors PD153035 (PD) or AG1478 (AG) before treatment with $25 \mu \mathrm{M} \Delta 2$-TGZ $(\Delta 2 \mathrm{~T})$ for 3 hours. Control cells were treated with $0.05 \%$ DMSO (D). mRNA expression was analyzed by RT-PCR as described in B. D, $\Delta 2$-TGZ-induced expression of EGRI mRNA and ERK phosphorylation after silencing of EGFR receptors by RNA interference. MCF7 cells were transiently transfected with double-strand siRNA targeting EGFR or control (Ctrl) siRNA. 48 hours after transfection, cells were exposed to 25 $\mu \mathrm{M} \Delta 2$-TGZ $(\Delta 2 \mathrm{~T})$ or $0.05 \%$ DMSO (D). After 3 hours treatment, the expressions of $E G F R$, 
EGR1 and RPLPO were analyzed at the mRNA level by RT-PCR. The amplified products were detected after agarose gel electrophoresis. After 30 minutes treatment, phospho-ERK1/2 and total ERK1/2 were analyzed by western blot.

Fig. 7. The PPAR $\gamma$-independent activation of EGR1 expression is also observed in the hormone-independent breast cancer cell line MDA-MB-231. MDA-MB-231 cells were pretreated with $5 \mu \mathrm{M}$ U0126 (specific inhibitor of MEK1/2) or $5 \mu \mathrm{M}$ AG1478 (AG; EGFR tyrosine kinase inhibitor) for 30 minutes before treatment with $25 \mu \mathrm{M} \Delta 2$-TGZ ( $\Delta 2 \mathrm{~T})$ for 3 hours. Control cells were treated with $0.05 \%$ DMSO (D, vehicle) or non-treated (NT). EGRl mRNA expression was analyzed by RT-PCR. The amplified products were detected after agarose gel electrophoresis. The housekeeping gene RPLPO was used as an internal control. The band intensities of EGR1 were evaluated in terms of optical density arbitrary units and normalized with the RPLPO signal intensity. Data are presented in the histogram.

Fig. 8. EGR1 expression and ERK1/2 phosphorylation depend on calcium mobilization. A, Inhibition of EGR1 mRNA expression and ERK1/2 phosphorylation in presence of the calcium chelator BAPTA-AM. MCF7 cells were pretreated with $50 \mu \mathrm{M}$ BAPTA-AM for 30 minutes before treatment with $25 \mu \mathrm{M} \Delta 2$-TGZ $(\Delta 2 \mathrm{~T})$, TGZ (T), CGZ (C) or 15d-PGJ2 (P) for 3 hours for EGRI expression detection. For ERK1/2 phosphorylation experiments, cells were treated with TGZ (T), CGZ (C) or 15d-PGJ2 (P) for 15 minutes and 30 minutes with $\Delta 2$-TGZ $(\Delta 2 \mathrm{~T})$. Control cells were treated with $0.05 \%$ DMSO (D). EGRI mRNA expression was analyzed by RT-PCR. The amplified products were detected after agarose gel electrophoresis and expressed relatively to the housekeeping gene RPLPO. To detect changes in ERK1/2 phosphorylation status, cells were harvested in $2 \mathrm{X}$ Laemmli buffer and total proteins were subjected to western blot analysis using anti-phospho-ERK1/2 antibody (P-ERK1/2). The 
blots were stripped and reprobed using antibody directed against total ERK1/2 (ERK1/2). B, Comparative study of EGRl mRNA expression induced by $\triangle 2$-TGZ and the A23187 ionophore in MCF7 cells. Cells were treated with $25 \mu \mathrm{M} \Delta 2$-TGZ $(\Delta 2 \mathrm{~T})$ and 1 or $5 \mu \mathrm{M}$ A23187 ionophore for the indicated times. Control cells were treated with $0.05 \%$ DMSO (D). EGR1 mRNA expression was analyzed by RT-PCR. The amplified products were detected after agarose gel electrophoresis and expressed relatively to the housekeeping gene RPLPO. C, Kinetic of ERK1/2 phosphorylation induced by the A23187 ionophore in MCF7 cells. Cells were treated with $1 \mu \mathrm{M}$ A23187 ionophore (A) for the indicated time and total proteins were subjected to western blot analysis as previously described. Control cells were treated with $0.05 \%$ DMSO (D). D, Cytoplasmic $\mathrm{Ca}^{2+}$ concentration was detected by the ratiometric fluorescent probe Fura-2. MCF7 cells were superfused with a saline solution and exposed during the indicated time to $0.05 \%$ DMSO (upper panel), $25 \mu \mathrm{M}$ TGZ (upper panel) or 25 $\mu \mathrm{M} \Delta 2$-TGZ (middle and lower panels). The effect of $\Delta 2$-TGZ was also studied in MCF7 cells pretreated with $50 \mu \mathrm{M}$ of the calcium chelator BAPTA-AM (middle panel) as well as in calcium-free conditions (lower panel). The results are expressed as mean (black lines) \pm s.e.m. (grey lines) of several measurements.

Fig. 9. EGR1 plays a part in the antiproliferative action of $\Delta 2$-TGZ. A, MCF7 cells were transiently transfected with double-strand siRNA targeting EGRl or control (Ctrl) siRNA. 48 hours after transfection, cells were exposed to $15 \mu \mathrm{M} \Delta 2$-TGZ ( $\Delta 2 \mathrm{~T})$ or $0.05 \%$ DMSO (D) for 3 hours. mRNA expression for EGRI and RPLPO was analyzed by RT-PCR. The amplified products were detected after agarose gel electrophoresis. B, 28 hours after control (Ctrl) and EGR1 siRNA transfection, cells were exposed to $15 \mu \mathrm{M} \Delta 2$-TGZ ( $\Delta 2 \mathrm{~T})$ or $0.05 \%$ DMSO (D) for 24 hours. The number of viable cells was measured using the CellTiter-GloTM 
Luminescent Cell Viability Assay. Results are given as mean \pm s.e.m. of cell number (arbitrary units) $(\mathrm{n}=5)$.

* Significantly different from Ctrl siRNA $(\mathrm{p}<0.01)$ using the unpaired t-Test. 
TABLE 1. siRNA sequences for PPAR $\boldsymbol{\gamma}$, EGF receptors, and EGR1. Sense and antisense oligonucleotides for each receptor gene were designed by Eurogentec (Angers, France). The sense (S) and antisense (AS) sequences for the siRNA duplexes are shown in the right column. TT did not belong to the target sequences and were added as 3' DNA over-hang. Control siRNA encodes random sequences with no homology to any known human genes.

\begin{tabular}{|c|c|c|c|c|}
\hline Gene & $\begin{array}{l}\text { Accession } \\
\text { number }\end{array}$ & & Target sequence (5'-3') & siRNA sequence (5'-3') \\
\hline PPAR $\gamma$ & NM_138712 & Duplex 1 & GTACCAAAGTGCAATCAAA & $\begin{array}{l}\text { S:GUACCAAAGUGCAAUCAAATT } \\
\text { AS:UUUGAUUGCACUUUGGUACTT }\end{array}$ \\
\hline & & Duplex 2 & CAATCAGATTGAAGCTTAT & $\begin{array}{l}\text { S:CAAUCAGAUUGAAGCUUAUTT } \\
\text { AS:AUAAGCUUCAAUCUGAUUGTT }\end{array}$ \\
\hline EGFR & NM_201283 & Duplex 1 & GCAGTGACTTTCTCAGCAA & $\begin{array}{l}\text { S:GCAGUGACUUUCUCAGCAATT } \\
\text { AS:UUGCUGAGAAAGUCACUGCTT }\end{array}$ \\
\hline & & Duplex 2 & GAGGAAATATGTACTACGA & $\begin{array}{l}\text { S:GAGGAAAUAUGUACUACGATT } \\
\text { AS:UCGUAGUACAUAUUUCCUCTT }\end{array}$ \\
\hline EGR1 & NM_001964.2 & & GTGACTGTTTG & $\begin{array}{l}\text { S:GUGACUGUUUGGCUUAUATT } \\
\text { AS:UUAUAAGCCAAACAGUCACTT }\end{array}$ \\
\hline $\begin{array}{l}\text { Negative } \\
\text { control }\end{array}$ & $\begin{array}{c}\text { Eurogentec } \\
\text { SR-CL000-005 }\end{array}$ & & none & non available \\
\hline
\end{tabular}




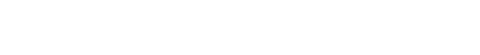

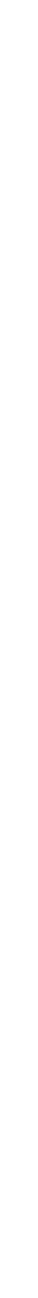


A

EGR1

NT $\frac{0.5 \mathrm{~h}}{\mathrm{D} \mathrm{C}} \frac{1 \mathrm{~h}}{\mathrm{D} \mathrm{C}} \frac{3 \mathrm{~h}}{\mathrm{D} \mathrm{C}} \frac{6 \mathrm{~h}}{\mathrm{D} \mathrm{C}} \frac{24 \mathrm{~h}}{\mathrm{D} \mathrm{C}}$

RPLPO

$\begin{array}{lllllllllll}\text { NT } & \mathrm{D} & \mathrm{P} & \mathrm{D} & \mathrm{P} & \mathrm{D} & \mathrm{P} & \mathrm{D} & \mathrm{P} & \mathrm{D} & \mathrm{P}\end{array}$

EGR1

RPLPO

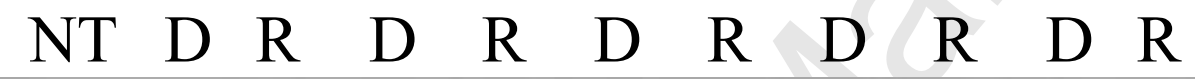

EGR1

RPLPO

B
$\begin{array}{lllll}D & \mathrm{C} & \mathrm{P} & \mathrm{R}\end{array}$

EGR1

$$
\frac{6 \mathrm{~h}}{\mathrm{D} \quad \mathrm{C}} \frac{9 \mathrm{~h}}{\mathrm{D} C \mathrm{C}} \frac{6 \mathrm{~h}}{\mathrm{D} P} \frac{9 \mathrm{~h}}{\mathrm{D} P}
$$

NAB2

RPLPO 
A

GW

${ }_{-}^{\mathrm{NT}} \frac{\mathrm{D}}{-525} \frac{\mathrm{T}}{-525} \frac{\mathrm{C}}{-525} \frac{\mathrm{P}}{-525}(\mu \mathrm{M})$

EGR1

RPLPO

B

Ctrl
siRNA $\frac{\begin{array}{c}\text { PPAR } \gamma \\ \text { siRNA }\end{array}}{\mathrm{D} \mathrm{T} \quad \mathrm{T}} \frac{\mathrm{D} \mathrm{T}}{\mathrm{D}}$

EGR1

PPAR $\gamma$

RPLPO

C

$$
\frac{1 \mathrm{~h}}{\mathrm{D} \Delta 2 \mathrm{~T}} \frac{3 \mathrm{~h}}{\mathrm{D} \Delta 2 \mathrm{~T}} \frac{6 \mathrm{~h}}{\mathrm{D} \Delta 2 \mathrm{~T}} \frac{9 \mathrm{~h}}{\mathrm{D} \Delta 2 \mathrm{~T}} \frac{16 \mathrm{~h}}{\mathrm{D} \Delta 2 \mathrm{~T}} \frac{24 \mathrm{~h}}{\mathrm{D} \Delta 2 \mathrm{~T}}
$$

EGR1

NAB2

RPLPO

D

D $\quad \mathrm{T} \quad \Delta 2 \mathrm{~T}$ 
A

$$
\frac{5 \min }{\mathrm{D} \mathrm{T} \mathrm{C} \mathrm{P} \mathrm{D} \mathrm{T} \mathrm{C} \mathrm{P}}
$$

$\mathrm{P}-\mathrm{ERK} 1 / 2==-==$

ERK1/2

$$
\frac{30 \mathrm{~min}}{\mathrm{D} \mathrm{T} \mathrm{C} \mathrm{P} \mathrm{D} \mathrm{T} \mathrm{C} \mathrm{P}}
$$

P-ERK $1 / 2=====$

ERK1/2

$$
\frac{60 \min }{\mathrm{D} \text { T C P D T C P }}
$$

P-ERK1/2

ERK1/2

B $\frac{5 \mathrm{~min}}{\mathrm{D} \Delta 2 \mathrm{~T}} \frac{15 \mathrm{~min}}{\mathrm{D} \Delta 2 \mathrm{~T}} \frac{30 \mathrm{~min}}{\mathrm{D} \Delta 2 \mathrm{~T}} \frac{45 \mathrm{~min}}{\mathrm{D} \Delta 2 \mathrm{~T}} \frac{60 \mathrm{~min}}{\mathrm{D} \Delta 2 \mathrm{~T}} \frac{75 \mathrm{~min}}{\mathrm{D} \Delta 2 \mathrm{~T}}$

P-ERK1/2

ERK1/2

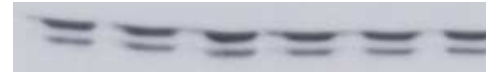

C

U0126

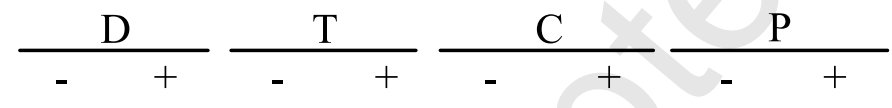

P-ERK1/2

ERK1/2

U0126

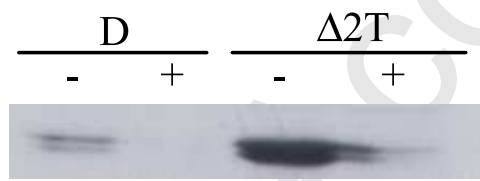

ERK1/2

D

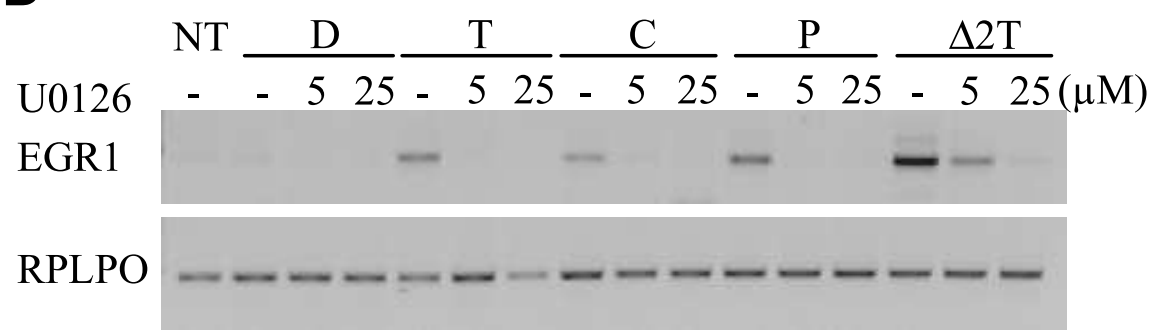

E 
A

$\begin{array}{lllllllllll}\text { SB203580 } & - & - & + & +\end{array}$

EGR1

RPLPO
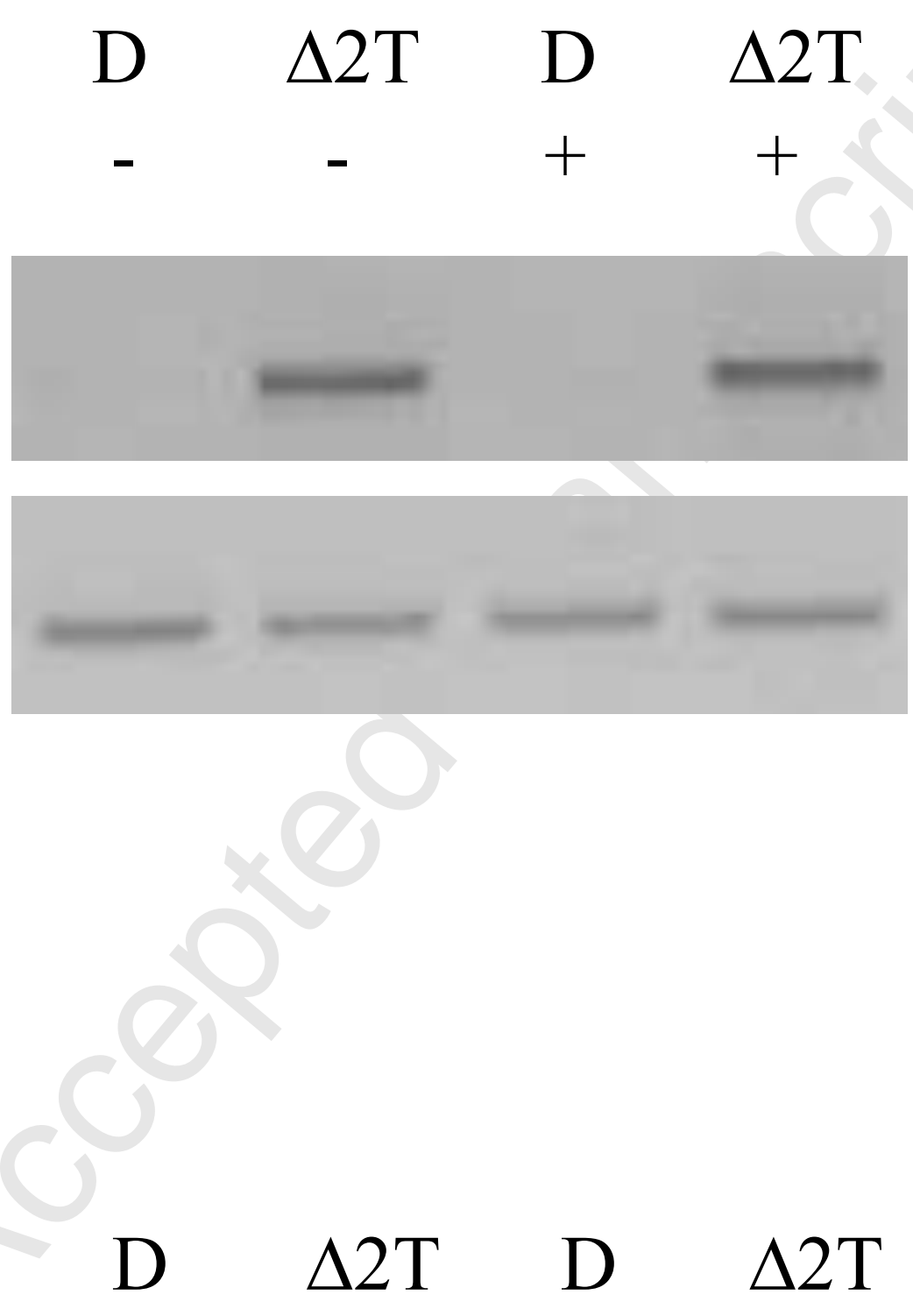

$\begin{array}{llllll}\text { SP600125 } & - & - & + & +\end{array}$

\author{
EGR1
}

RPLPO 
A

EGF $\frac{\mathrm{D}}{-+} \frac{\mathrm{PD} 5}{-} \frac{\mathrm{AG} 5}{-+}(\mu \mathrm{M})$

P-ERK1/2

ERK1/2

B

EGF $\quad$ NT $\frac{\mathrm{D}}{-+} \frac{\text { PD 5 }}{-+} \frac{\text { AG } 5}{-+}(\mu \mathrm{M})$

EGR1

RPLPO

$\Delta 2 \mathrm{~T} \quad \frac{\mathrm{D}}{-\quad+} \frac{\mathrm{PD} 5}{-++} \frac{\mathrm{AG} 5}{-+}(\mu \mathrm{M})$

EGR1

RPLPO

D

siRNA Ctrl EGFR

D $\Delta 2 \mathrm{~T} \quad \Delta 2 \mathrm{~T}$

EGFR

EGR1

RPLPO

P-ERK1/2

ERK1/2 


\section{FIGURE 7}

NT
$\Delta 2 \mathrm{~T}$
EGR1
RPLPO
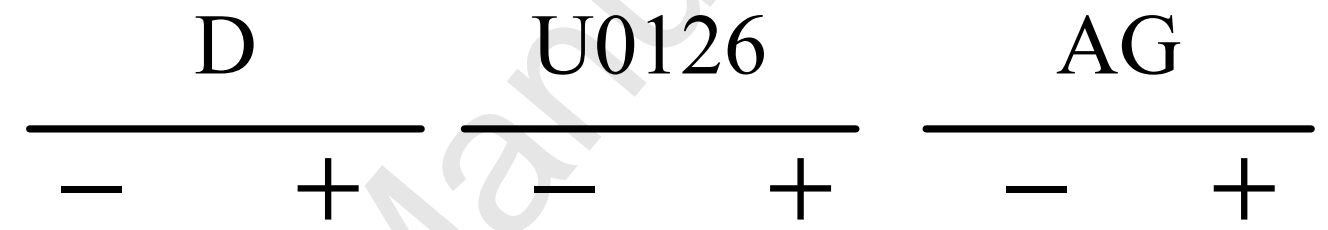

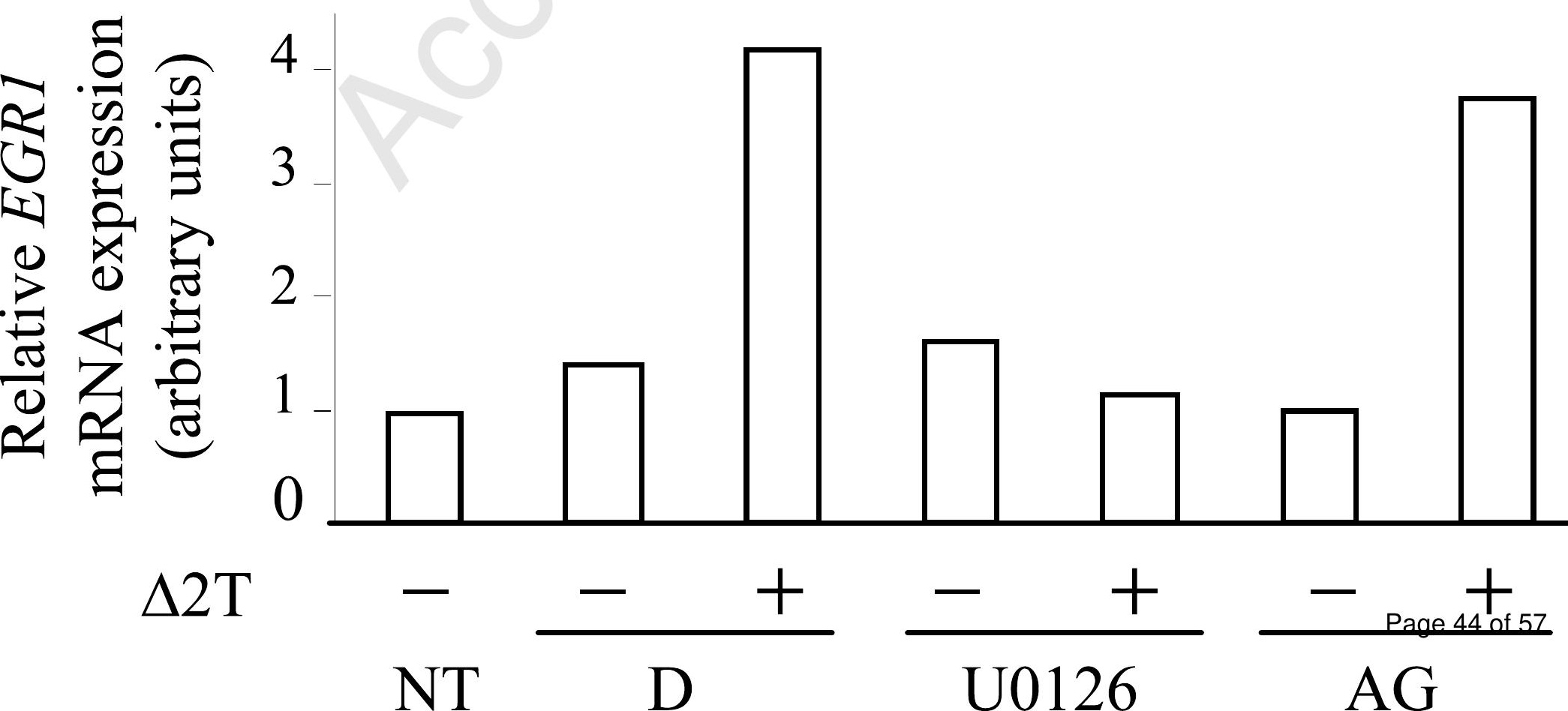




\section{FIGURE 8}

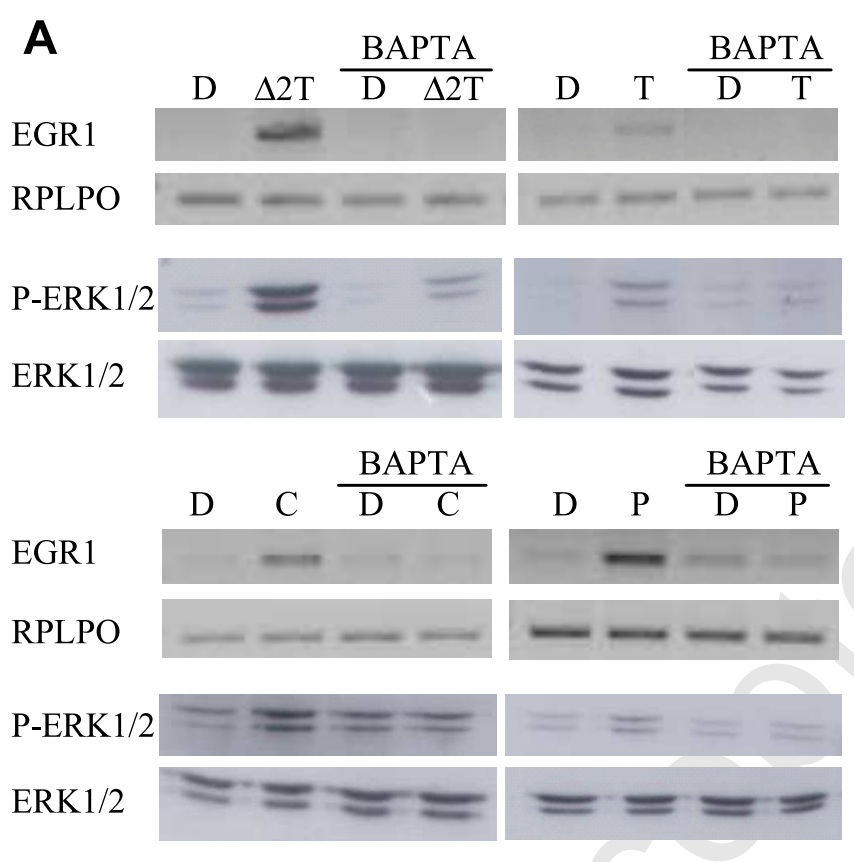

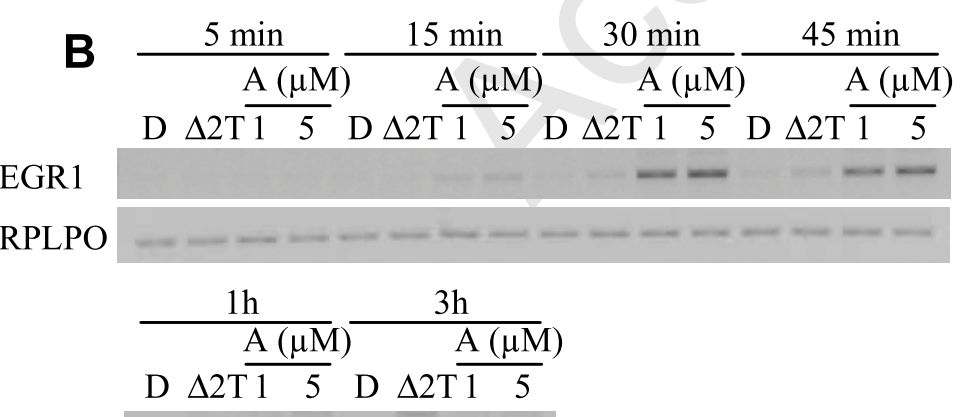

EGR

RPLPO

C $\frac{2 \min }{\mathrm{D} A} \frac{5 \min }{\mathrm{D} A} \frac{15 \min }{\mathrm{D} A \mathrm{~A}} \frac{30 \min }{\mathrm{D} A}$
D
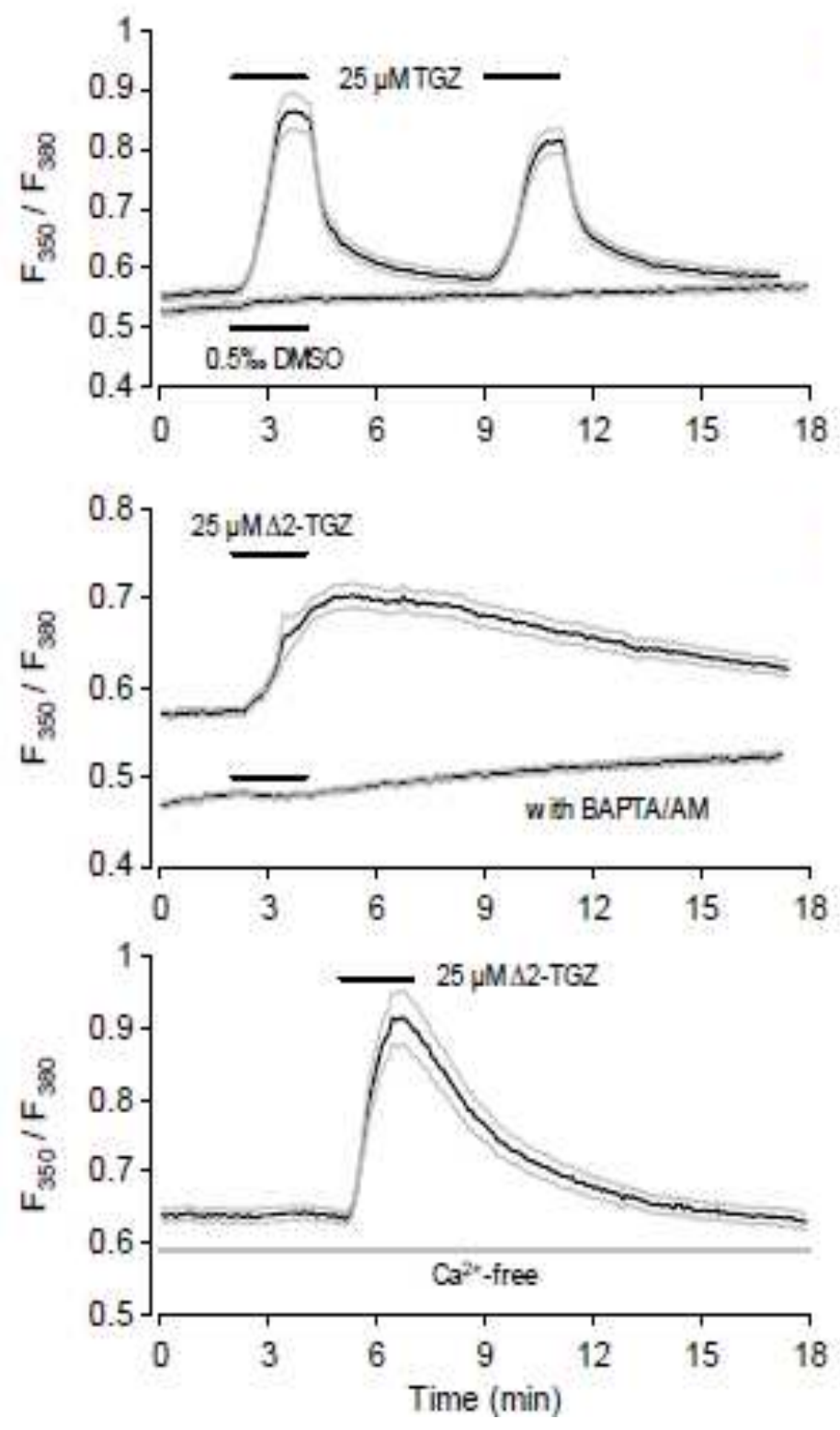

Page 45 of 57 


\section{FIGURE 1}

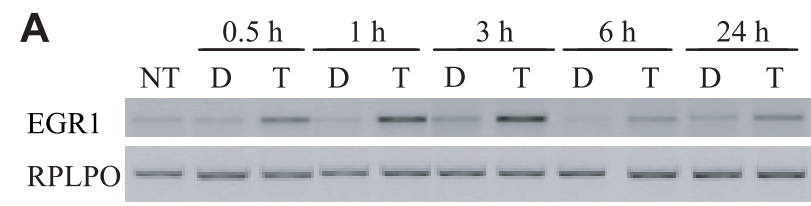

B

NT D $\frac{\mathrm{T}(\mathrm{\mu M})}{2512.55}$
EGR1
RPLPO ----

C

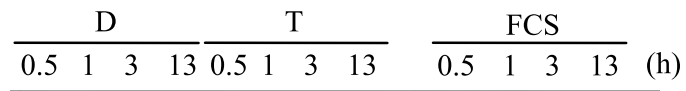

EGR1

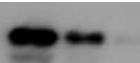

D

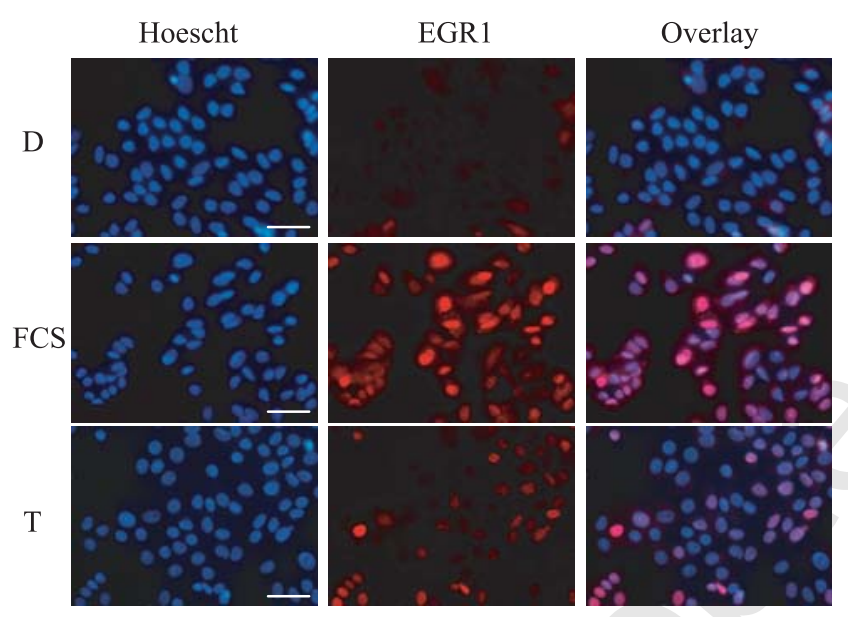

E

$$
\frac{1 \mathrm{~h}}{\mathrm{D} T \mathrm{~T}} \frac{3 \mathrm{~h}}{\mathrm{D} T} \frac{6 \mathrm{~h}}{\mathrm{D} T} \frac{9 \mathrm{~h}}{\mathrm{D} T} \frac{16 \mathrm{~h}}{\mathrm{D} T} \frac{24 \mathrm{~h}}{\mathrm{D} T}
$$

NAB2

RPLPO

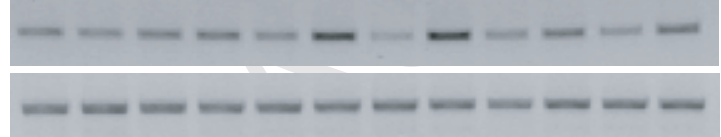




\section{FIGURE 2}

A

$$
\text { NT } \frac{0.5 \mathrm{~h}}{\mathrm{D} C} \frac{1 \mathrm{~h}}{\mathrm{D} C} \frac{3 \mathrm{~h}}{\mathrm{D} C} \frac{6 \mathrm{~h}}{\mathrm{D} C} \frac{24 \mathrm{~h}}{\mathrm{D} C}
$$

EGR1

RPLPO

$\begin{array}{lllllllllll}\text { NT } & \text { D } & \text { P } & \text { D } & \text { P } & \text { D } & \text { P } & \text { D } & \text { P } & \text { D } & \text { P }\end{array}$

EGR1

RPLPO

$$
\begin{array}{llllllllllll} 
& N T & D & R & D & R & D & R & D & R & D & R
\end{array}
$$

EGR1

RPLPO

B

$\begin{array}{rrrrrr} & \text { D } & \text { C } & \text { P } & \text { R } \\ \text { EGR1 } & - & & & & \end{array}$

C

$$
\frac{6 h}{D \quad C} \frac{9 h}{D \quad C} \frac{6 h}{D \quad P} \frac{9 h}{D \quad P}
$$

NAB2

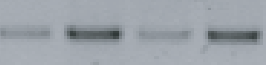

RPLPO 


\section{FIGURE 3}

A

GW $\quad$ NT $\frac{\mathrm{D}}{-525} \frac{\mathrm{T}}{-525} \frac{\mathrm{C}}{-525} \frac{\mathrm{P}}{-525}(\mu \mathrm{M})$

EGR1 - - - - - - - -

$\mathrm{RPLPO}--------\div-\div$

B Ctrl PPAR $\gamma$

SiRNA $\frac{\text { siRNA }}{\mathrm{D} T \mathrm{~T}}$

EGR1 -2 -

PPAR $\gamma$

RPLPO ---

C

$\frac{1 \mathrm{~h}}{\mathrm{D} \Delta 2 \mathrm{~T}} \frac{3 \mathrm{~h}}{\mathrm{D} \Delta 2 \mathrm{~T}} \frac{6 \mathrm{~h}}{\mathrm{D} \Delta 2 \mathrm{~T}} \frac{9 \mathrm{~h}}{\mathrm{D} \Delta 2 \mathrm{~T}} \frac{16 \mathrm{~h}}{\mathrm{D} \Delta 2 \mathrm{~T}} \frac{24 \mathrm{~h}}{\mathrm{D} \Delta 2 \mathrm{~T}}$

EGR1

NAB2

$\mathrm{RPLPO}--\div--\div-\div-\div-$

D

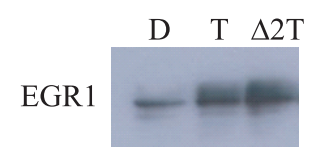




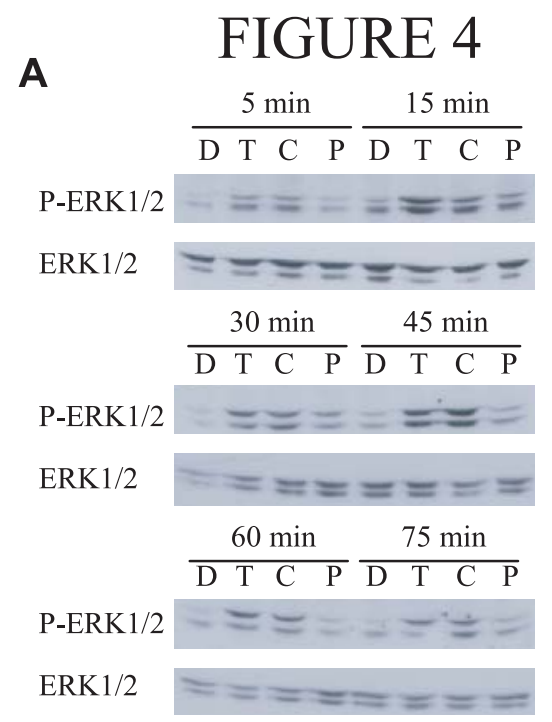

\section{B}

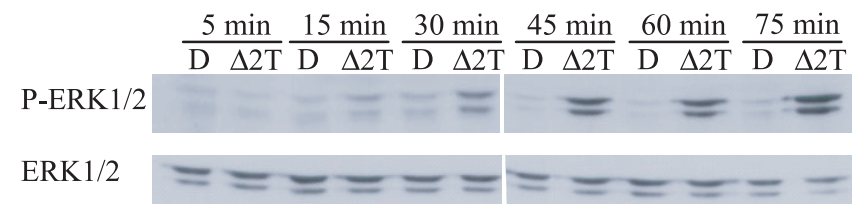

C
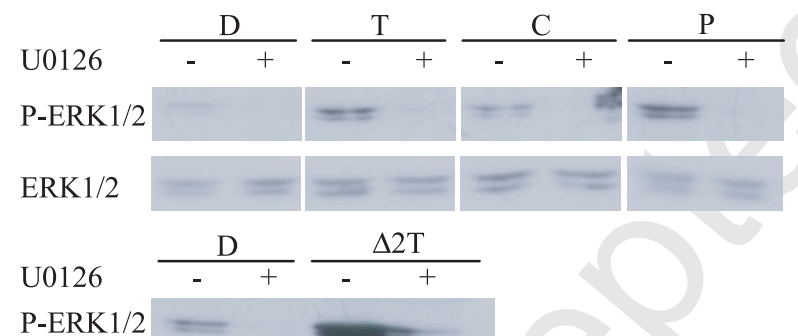

P-ERK1/2

ERK1/2

D

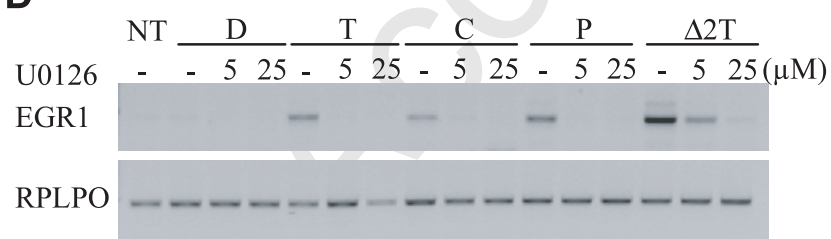

E

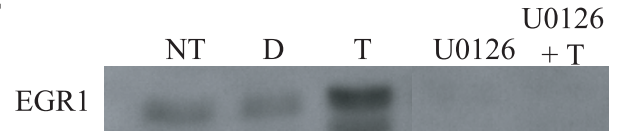




\section{FIGURE 5}

A

\begin{tabular}{|c|c|c|c|c|}
\hline & $\mathrm{D}$ & $\Delta 2 \mathrm{~T}$ & D & $\Delta 2 \mathrm{~T}$ \\
\hline SB203580 & - & - & + & + \\
\hline EGR1 & & - & & - \\
\hline RPLPO & - & - & - & - \\
\hline
\end{tabular}

B

$\begin{array}{ccccc} & \mathrm{D} & \Delta 2 \mathrm{~T} & \mathrm{D} & \Delta 2 \mathrm{~T} \\ \text { SP600125 } & - & - & + & + \\ \text { EGR1 } & & & & \\ & & & & \\ \text { RPLPO } & & & & \end{array}$




\section{FIGURE 6}

A

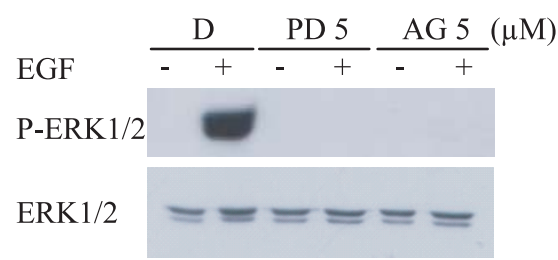

B

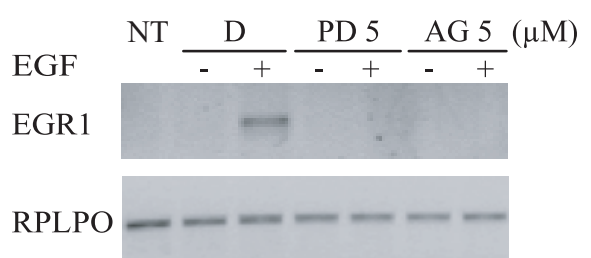

C

$\Delta 2 \mathrm{~T} \quad \frac{\mathrm{D}}{-\quad+} \frac{\mathrm{PD} 5}{-} \frac{\mathrm{AG} 5}{-+}(\mu \mathrm{M})$

EGR1

RPLPO

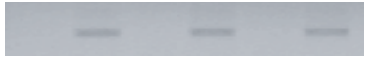

D

\begin{tabular}{|c|c|c|c|}
\hline siRNA & & trl & EGFR \\
\hline & $\mathrm{D}$ & $\Delta 2 T$ & $\Delta 2 \mathrm{~T}$ \\
\hline EGFR & $=$ & $=$ & \\
\hline EGR1 & & - & \\
\hline RPLPO & - & 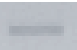 & \\
\hline P-ERK1/2 & & $=$ & $=$ \\
\hline ERK $1 / 2$ & $=$ & $\equiv$ & $=$ \\
\hline
\end{tabular}




\section{FIGURE 7}
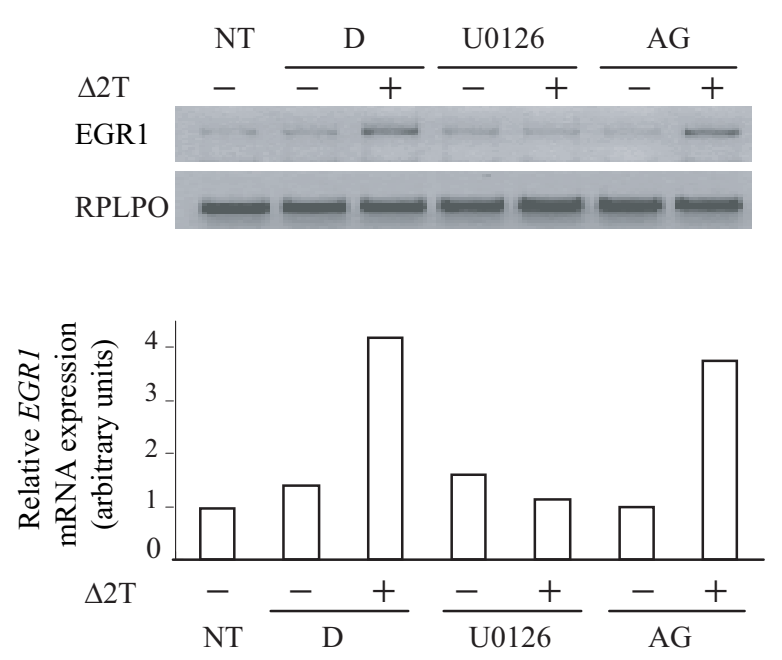


\section{FIGURE 8}

A
$\mathrm{D} \quad \Delta 2 \mathrm{~T} \frac{\mathrm{BAPTA}}{\mathrm{D} \quad \Delta 2 \mathrm{~T}} \quad \mathrm{D} \quad \mathrm{T} \frac{\mathrm{BAPTA}}{\mathrm{D} \quad \mathrm{T}}$

EGR1

RPLPO

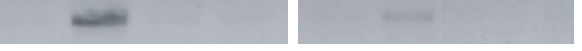

P-ERK1/2

ERK $1 / 2$

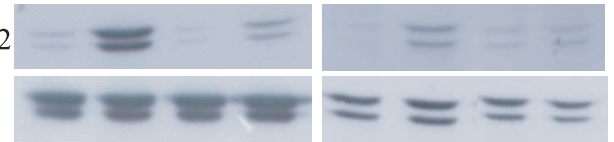

D $\quad \mathrm{C} \frac{\mathrm{BAPTA}}{\mathrm{D} \quad \mathrm{C}} \quad \mathrm{D} \quad \mathrm{P} \frac{\mathrm{BAPTA}}{\mathrm{D} \quad \mathrm{P}}$

EGR1

RPLPO

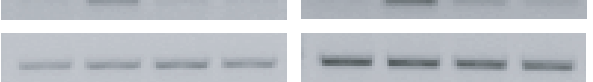

P-ERK1/2

ERK $1 / 2$

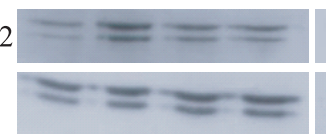

B $\frac{5 \min }{\mathrm{A}(\mu \mathrm{M})} \frac{15 \mathrm{~min}}{\mathrm{~A}(\mu \mathrm{M})} \frac{30 \mathrm{~min}}{\mathrm{~A}(\mu \mathrm{M})} \frac{45 \mathrm{~min}}{\mathrm{~A}(\mu \mathrm{M})}$ $\mathrm{D} \Delta 2 \mathrm{~T} \overline{15} \mathrm{D} \Delta 2 \mathrm{~T} \overline{15} \mathrm{D} \Delta 2 \mathrm{~T} \overline{15} \mathrm{D} \Delta 2 \mathrm{~T} \overline{15}$

EGR1

RPLPO

$$
\frac{1 \mathrm{~h}}{\mathrm{~A} \Delta 2 \mathrm{~T}(\mu \mathrm{M})} \frac{3 \mathrm{~h}}{\frac{\mathrm{A}(\mu \mathrm{M})}{5}}
$$

EGR1

RPLPO

C $\frac{2 \min }{\mathrm{D} A} \frac{5 \min }{\mathrm{D} A} \frac{15 \min }{\mathrm{D} A} \frac{30 \min }{\mathrm{D} A}$

P-ERK1/2

ERK1/2
D
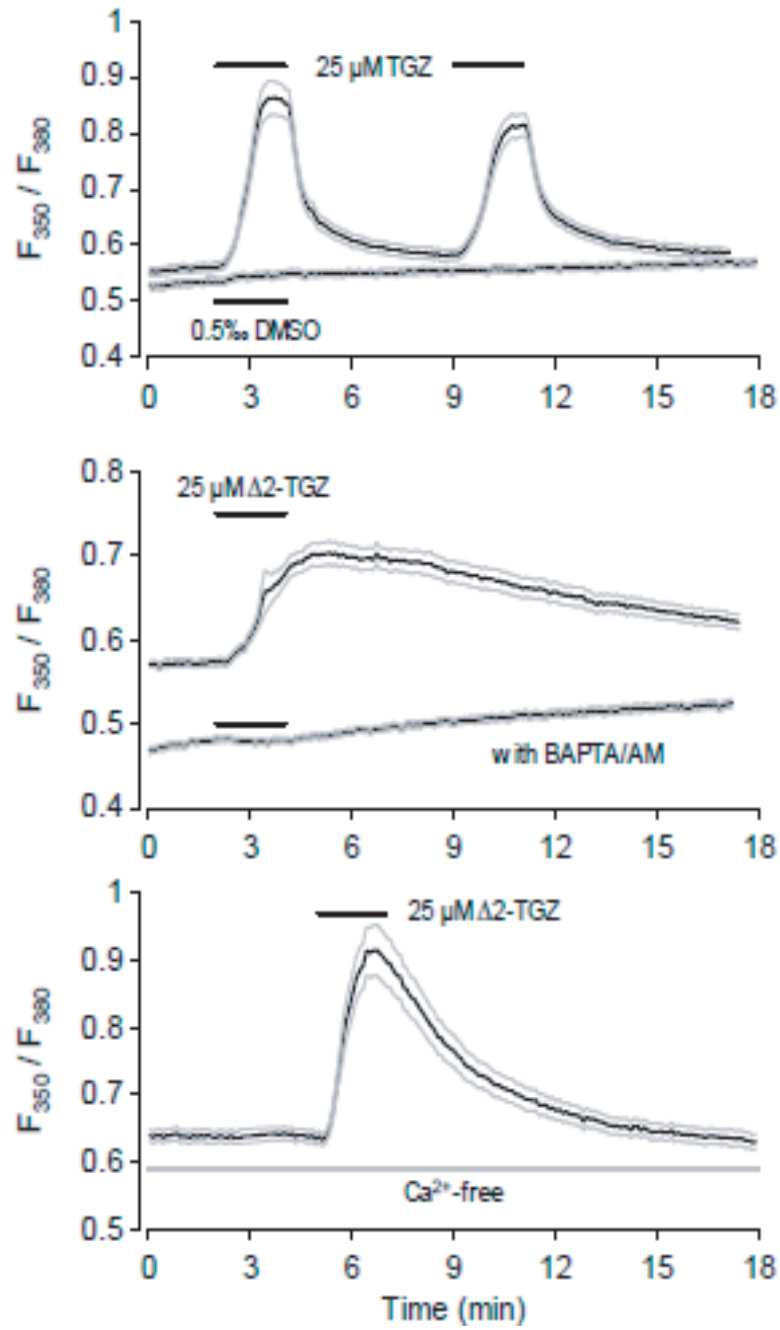


\section{FIGURE 9}

A

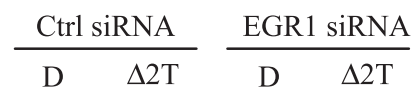

EGR1

RPLPO

B

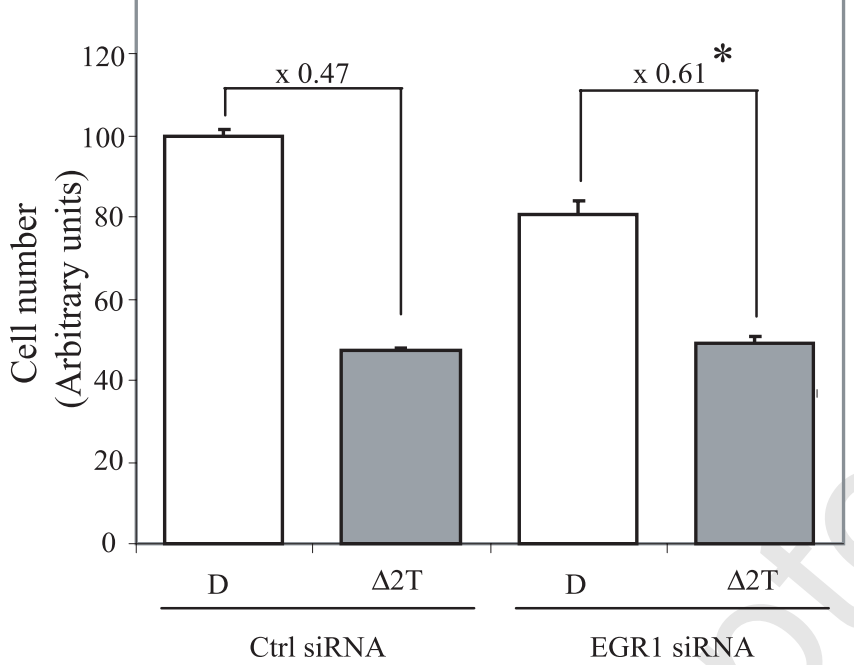




\section{TGZ/A2-TGZ}

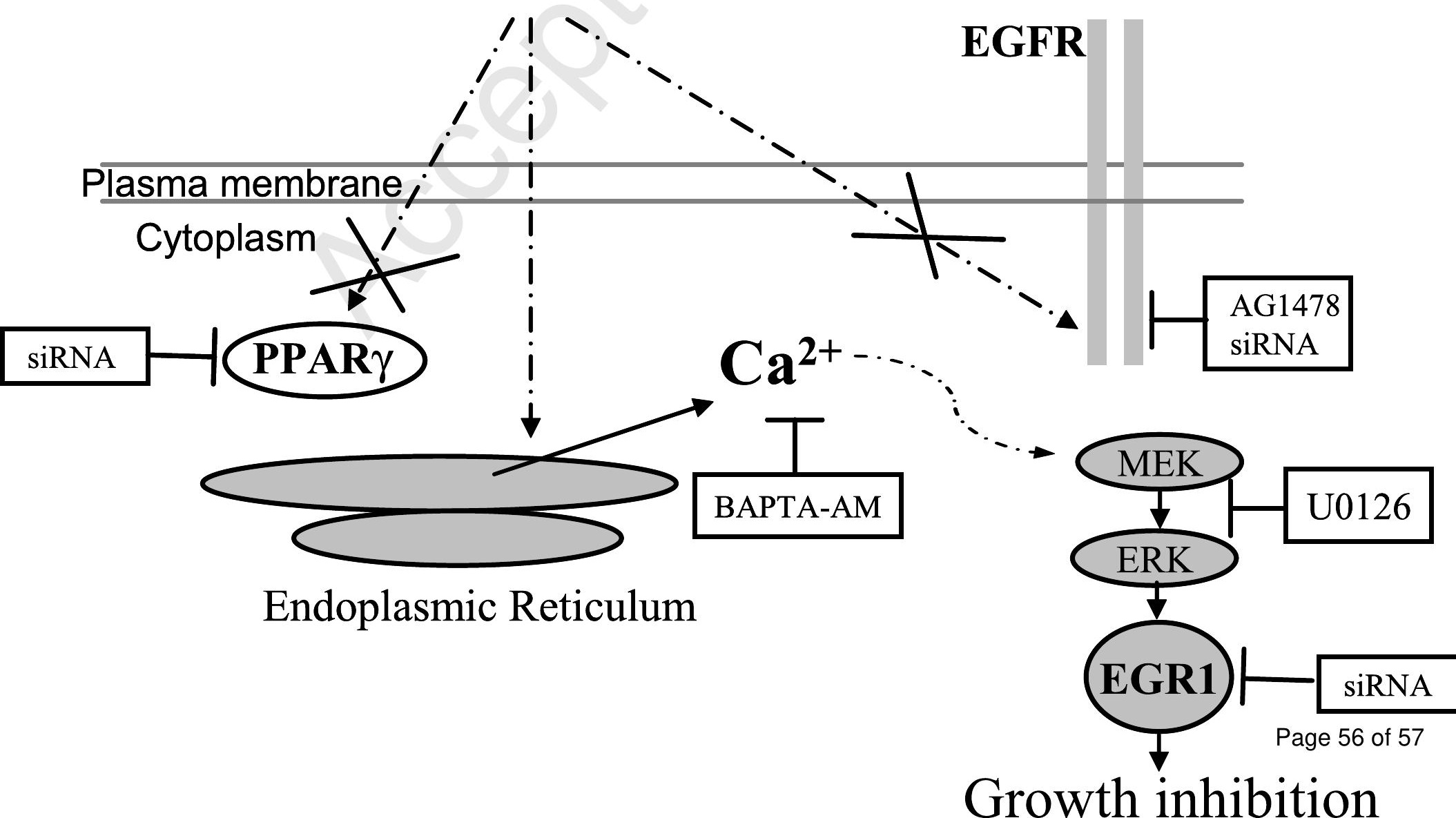




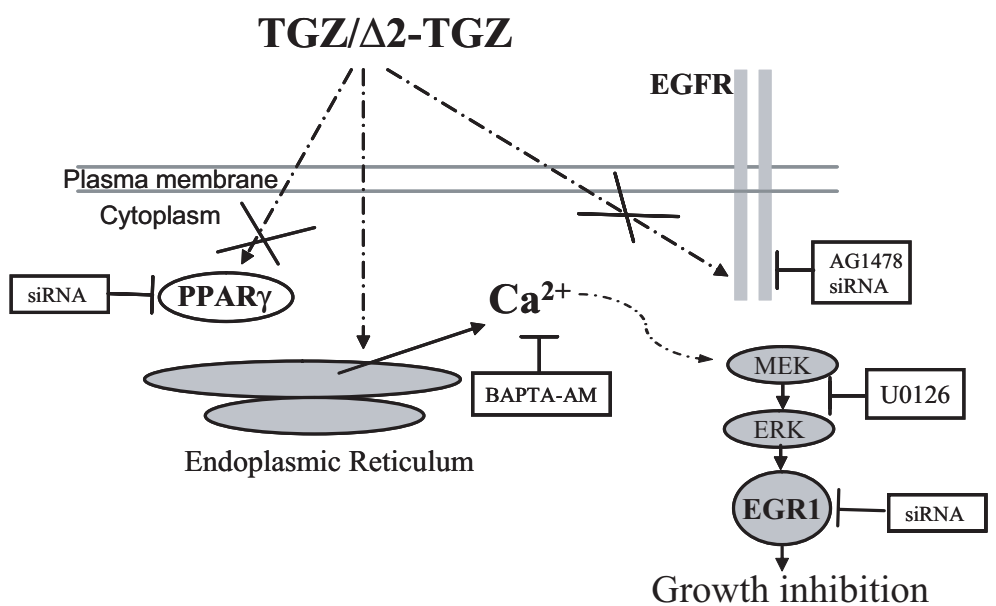

